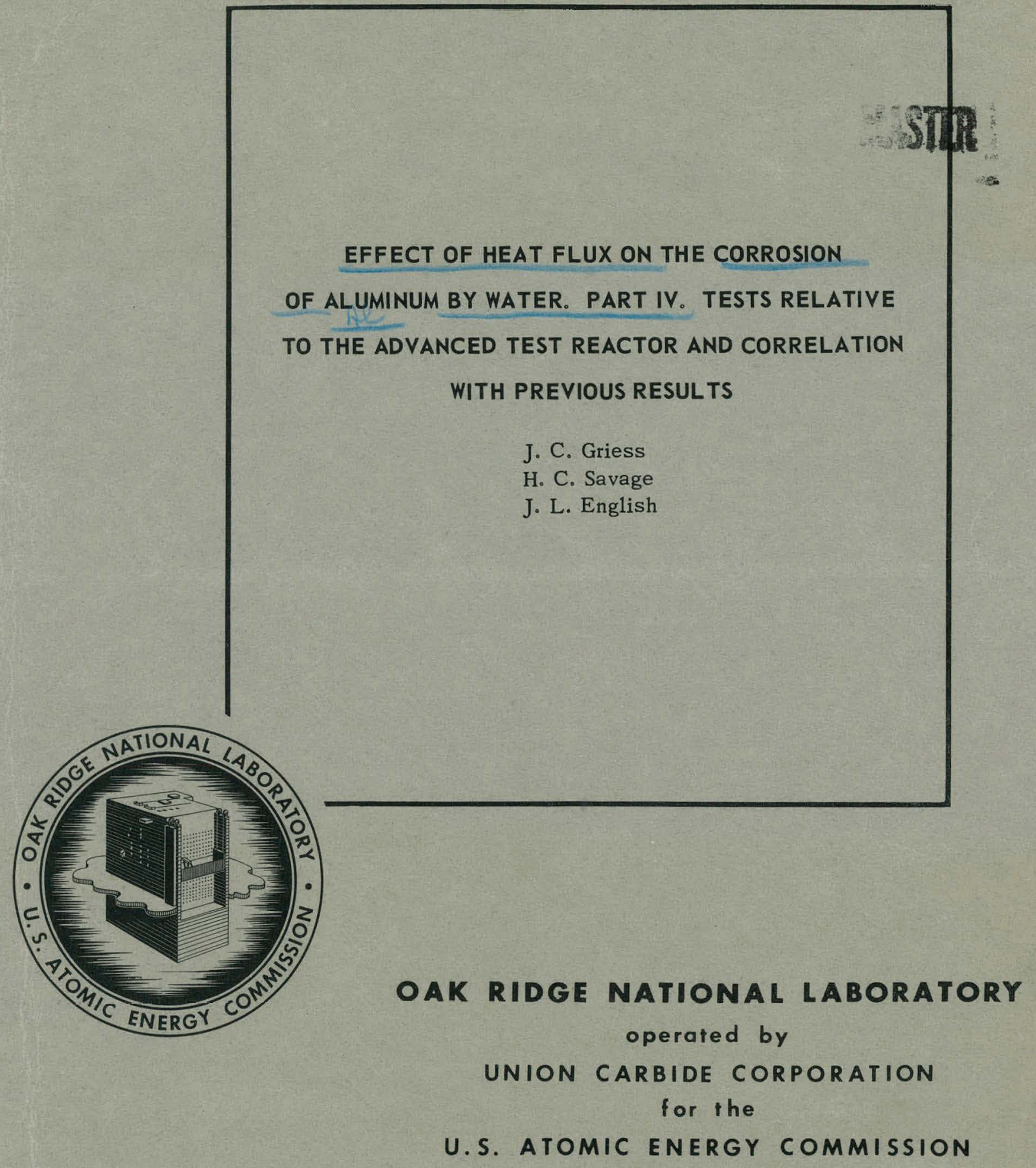




\section{DISCLAIMER}

This report was prepared as an account of work sponsored by an agency of the United States Government. Neither the United States Government nor any agency Thereof, nor any of their employees, makes any warranty, express or implied, or assumes any legal liability or responsibility for the accuracy, completeness, or usefulness of any information, apparatus, product, or process disclosed, or represents that its use would not infringe privately owned rights. Reference herein to any specific commercial product, process, or service by trade name, trademark, manufacturer, or otherwise does not necessarily constitute or imply its endorsement, recommendation, or favoring by the United States Government or any agency thereof. The views and opinions of authors expressed herein do not necessarily state or reflect those of the United States Government or any agency thereof. 


\section{DISCLAIMER}

Portions of this document may be illegible in electronic image products. Images are produced from the best available original document. 
Printed in USA. Price: $\$ 1.00$ Available from the Office of Technical Services

U. S. Department of Commerce

Washington 25, D. C.

\section{LEGAL NOTICE}

This report was prepared as an account of Government sponsored work. Neither the United States, nor the Commission, nor any person acting on behalf of the Commission:

A. Makes any warranty or representation, expressed or implied, with respect to the accuracy, completeness, or usefulness of the information contained in this report, or that the use of any information, apparatus, method, or process disclosed in this report may not infringe privately owned rights; or

B. Assumes any liabilities with respect to the use of, or for damages resulting from the use of any information, apparatus, method, or process disclosed in this report.

As used in the above, "person acting on behalf of the Commission" includes any employee or contractor of the Commission, or employee of such contractor, to the extent that such employee or contractor of the Commission, or employee of such contractor prepares, disseminates, or provides access to, any information pursuant to his employment or contract with the Commission, or his employment with such contractor. 


\section{EFFECT OF HEAT FLUX ON THE CORROSION OF ALUMINUM BY WATER. \\ PART IV. TESTS RELATIVE TO THE ADVANC ED TEST REACTOR AND CORRELATION WITH PREVIOUS RESULTS}

J. C. Griess

H. C. Savage

J. L. English

is

FEBRUARY 1964

two

\footnotetext{
OAK RIDGE NATIONAL LABORATORY

Oak Ridge, Tennessee

operoted by

UNION CARBIDE CORPORATION

for the
}

U.S. ATOMIC ENERGY COMMISSION 
THIS PAGE

WAS INTENTIONALLY

LEFT BLANK 


\section{CONTENTS}

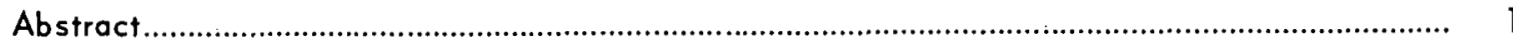

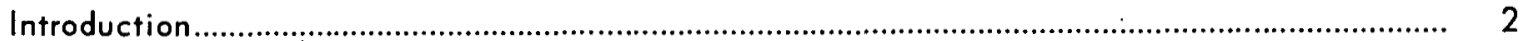

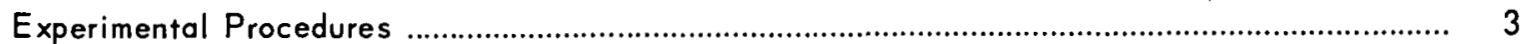

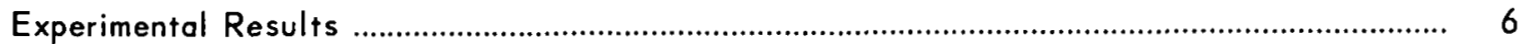

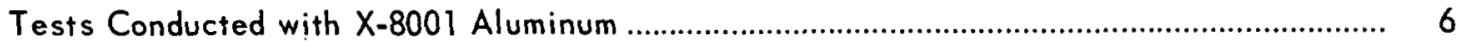

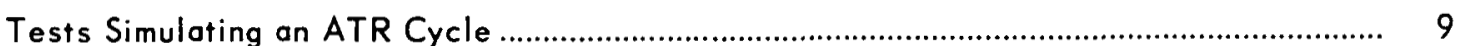

Effect of Thermal Cycling on the Spalling of Oxide ............................................................. 12

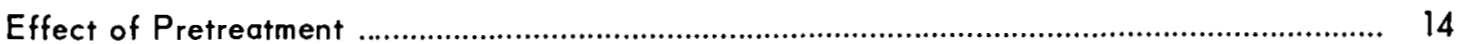

Thermal Conductivity of Corrosion Product Film................................................................. 18

Effect of Time and Temperature on Oxide Formation ...................................................... 18

Effect of Heat Transfer Rate............................................................................................... 20

Effect of $\mathrm{pH}$

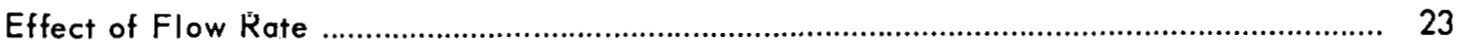

Correlation of Oxide Buildup with Exposure Time and Temperature.................................... 24

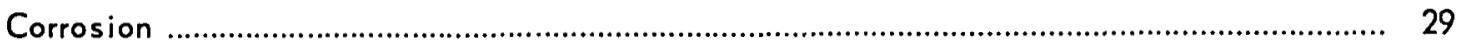

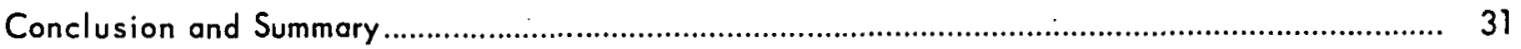




\title{
EFFECT OF HEAT FLUX ON THE CORROSION OF ALUMINUM BY WATER. PART IV. TESTS RELATIVE TO THE ADVANCED TEST REACTOR AND CORRELATION WITH PREVIOUS RESULTS
}

\author{
J. C. Griess \\ H. C. Savage \\ J. L. English
}

\section{ABSTRACT}

The corrosion of 6061 and $X-8001$ aluminum alloys and the resultant formation of an adherent corrosion product on the corroding surface were investigated under conditions (except radiation) comparable to those that will exist on the surface of fuel-element cladding during operation of the Advanced Test Reactor. Since previous experiments indicated that corrosion penetration of the aluminum clad was unlikely during a reactor cycle provided the water chemistry is properly controlled, most of the studies in this investigation were concerned with the effect of variables on the rate of formation of corrosion-product films. These films have low thermal conductivity and can be a major factor in producing high fuel-element temperatures which lead to fuel-plate instabilities. The experimental procedures were the same as used in a similar study for the High Flux Isotope Reactor, but the ranges of variables investigated were greater than in previous studies.

The 6061 and $X-8001$ alloys corroded to the same extent under the same test conditions until the corrosion product (boehmite) that formed on the surface became thick enough to spall spontaneously from the surface, usually about 2 mils thick. Spallation from the surface of the 6061 alloy was always accompanied by localized attack of the underlying metal, whereas only uniform attack was observed with the X-8001 alloy under all conditions. Previously it was shown that the 1100 aluminum alloy behaved like the 6061 alloy in all respects.

All three alloys developed corrosion-product coatings at the same rate when tested under the same conditions. The thermal conductivity of the corrosion product was determined to be $1.3 \mathrm{Btu} \mathrm{hr}^{-1} \mathrm{ft}^{-1}\left({ }^{\circ} \mathrm{F}\right)^{-1}$. The $\mathrm{pH}$ of the water was an important wariable in determining the rate of corrosion-product buildup on aluminum. Under the same conditions the rate of oxide formation was 2.7 times greater when the $\mathrm{pH}$ of the water was 5.7 to 7.0 than when the $\mathrm{pH}$ was 5.0 (with nitric acid); $\mathrm{pH}$ was not a significant variable within the former range. Changes in $\mathrm{pH}$ during a test resulted in abrupt changes in the rate of oxide formation and presumably also in corrosion. The data indicated that up to the point of film spallation about $70 \%$ of the aluminum that was oxidized remained on the surface as boehmite regardless of test conditions; the rest was lost to the water.

The rate of oxide formation on the specimens decreased with exposure time and increased as the surface temperature increased. The controlling temperature was that at the aluminum oxide-water interface (surface temperature). Considering only the data acquired with the water at a coolant $\mathrm{pH}$ of 5.0 and at heat fluxes between 1 and $2 \times 10^{6} \mathrm{Btu} \mathrm{hr}^{-1} \mathrm{ft}^{-2}$, the thickness of oxide built up on the corroding surface was described reasonably well by the empirical equation

$$
X=443 \theta^{0.778} \exp \left(\frac{-4600}{K}\right),
$$

where $X$ is corrosion-product thickness in mils, $\theta$ is time in hours, and $K$ is surface temperature in degrees Kelvin. With $\mathrm{pH}$ values between 5.7 and 7.0 the same relation applied except that the first coefficient in the above equation was 1200 
instead of 443. Within the range of 1 to $2 \times 10^{6} \mathrm{Btu} \mathrm{hr}^{-1} \mathrm{ft}^{-2}$, heat flux was unimportant except in the manner in which it influenced surface temperatures. Below $1 \times 10^{6} \mathrm{Btu} \mathrm{hr}^{-1} \mathrm{ft}^{-2}$, heat flux per se was a significant variable; considerably lower oxide thicknesses were observed than calculated by the above correlation.

The results of the experimental program indicate that the 6061 aluminum alloy, which has mechanical strength superior to either 1100 or X-8001, will have adequate corrosion resistance for use as cladding for both the Advanced Test Reactor and the High Flux Isotope Reactor fuel plates, provided the $\mathrm{pH}$ of the water is maintained at 5.0 with nitric acid. However, the increase in fuel-plate temperatures resulting from the buildup of the corrosion-product layer must be evaluated carefully to determine its effect of the mechanical and irradiation behavior of individual fuel plates and on the overall fuel-element stability.

\section{INTRODUCTION}

Two very high-performance reactors, the Advanced Test Reactor (ATR) and the High Flux Isotope Reactor (HFIR), are presently being built. The design parameters and the operating conditions for both reactors have been reported. ${ }^{1,2}$ Both will use thin aluminum-clad, plate-type fuel elements which will be cooled by water flowing at rates of 40 to $45 \mathrm{fps}$ through narrow coolant channels. High power densities can result in hot-spot heat fluxes as high as $2 \times 10^{6} \mathrm{Btu} \mathrm{hr}^{-1}$ $\mathrm{ft}^{-2}$. Although the temperature of the bulk cooling water will be less than $200^{\circ} \mathrm{F}$, the high heat fluxes across the cladding will produce surface temperatures high enough to make corrosion a potential problem.

Because of the high power densities in the reactor cores, the lives of the fuel elements will be short (10 to 15 days for the HFIR and 17 days for the ATR), and therefore corrosion rates higher than could be tolerated in pool-type research reactors or conventional power reactors are permissible. However, the corrosion of aluminum leads to the formation of a more or less adherent layer of corrosion product (boehmite) which by virtue of its low thermal conductivity presents a significant barrier to the transfer of heat across the cladding. Thus, as an aluminum-clad fuel element corrodes at constant heat flux, the fuel-plate temperature rises as the thickness of the corrosion product increases. Since aluminum has low mechanical strength which decreases rapidly as the temperature increases, and since in both reactors the aluminum cladding provides mechanical stability to the fuel plates, the insulation provided by the corrosion-product film can be more ot a limitation on the use of alumınum-clad fuel elements in high fluxi reacictors than is corrosion damage per se. In both reactors the fuel plates are separated by narrow cooling channels (50 or $78 \mathrm{mils}$ ) and any mechanical deflection or creep of the plates will significantly restrict the flow of coolant and, in the worst cases, lead to burnout of part of the fuel plates. Preliminary

\footnotetext{
${ }^{1}$ D. R. De Boisblanc et al., Advanced Test Reactor - ATR Final Conceptual Design, IDO-16667 (Nov. 1, 1960).

${ }^{2}$ J. R. McWherter and T. G. Chapman, "Mechanical Design of the HFIR," Book 1, pp 99-111 in Research Reactor Fuel Element Conference, Gatlinburg, Tenn., September 17-19, 1962, TID-7642.
} 
data indicated that with proper water treatment corrosion damage of the aluminum cladding is not likely to be severe in either reactor but that fuel plate temperatures would be high enough to make careful fuel-element design essential. ${ }^{3}$ Elevated-temperature creep data on 6061 and X-8001 aluminum alloys show that both materials suffer significant loss in creep resistance at temperatures much above $400^{\circ} \mathrm{F} .{ }^{4}$ To preserve mechanical stability, the refore, fuel-plate temperatures over any appreciable area should be limited to $400^{\circ} \mathrm{F} .{ }^{5}$ In the present investigation, most of the effort has been directed to determining the effect of variables on oxide formation and fuel-plate temperatures.

- Previously, results were reported on the effect of heat flux on the corrosion of aluminum under conditions that will exist during operation of the HFIR. ${ }^{3}$ The corrosion resistance of only two aluminum alloys, 6061 and 1100, was explored. In the present report, data obtained under sponsorship of the Advanced Test Reactor Program are reported. In this investigation, 6061 and X-8001 aluminum alloys were used; and, in general, the ranges of variables were extended beyond those examined in the previous work. In addition all data acquired at ORNL concerning the effect of heat flux on the corrosion of aluminum were evaluated, and a correlation was developed that makes possible reasonable predictions of corrosion-product buildup on aluminum surfaces under conditions comparable to those that will exist in the ATR and HFIR.

\section{EXPERIMENTAL PROCEDURES}

The experimental techniques used to obtain the results presented in this report have been described in detail ${ }^{6}$ and only a brief résumé is given here. In all tests a 6.5 -in.-long specimen that contained a center rectangular flow channel 0.078 in. by 0.500 in. was used. A sketch of the specimen is shown in Fig. 1. The 0.078-in. dimension is the same as the width of the coolant channels between plates in the ATR. In previous tests this dimension was 0.050 in., which is the fuel plate spacing in the HFIR. Each specimen was made in two axial halves which were welded together along the sides. Welded to each end of the specimen were aluminum electrodes to which the transformer leads were connected and by means of which the specimen was flanged into a bypass line of a stainless steel pump loop. As indicated in Fig. 1, eight thermocouples were spotwelded to the outside of the specimen which was insulated with close-fitting Mycalex. plates so that all heat generated in the specimen was removed by the coolant flowing through the central channel. The Mycalex plates were surrounded with stainless steel plates so that the specimen could withetand internal preseures as high as 1000 psi.

\footnotetext{
${ }^{3}$ J. C. Griess et al., Effect of Heat Flux on the Corrosion of Aluminum by Water. Part III. Final Report on Tests Relative to the High-Flux Isotope Reactor, ORNL-3230 (Dec. 5, 1961).

${ }^{4}$ W. R. Martin and J. R. Weir, Mechanical Properties of X-8001 and 6061 Aluminum Alloys and Aluminum Base Fuel Dispersions, to be published.

${ }^{5}$ R. J. Beaver, private communication.

${ }^{\circ} \mathrm{J}$. C. Griess et al., Effect of Heat Flux on the Corrosion of Aluminum by Water. Part I. Experimental Equipment and Preliminary Test Results, ORNL-2939 (Apr. 29, 1960).
} 


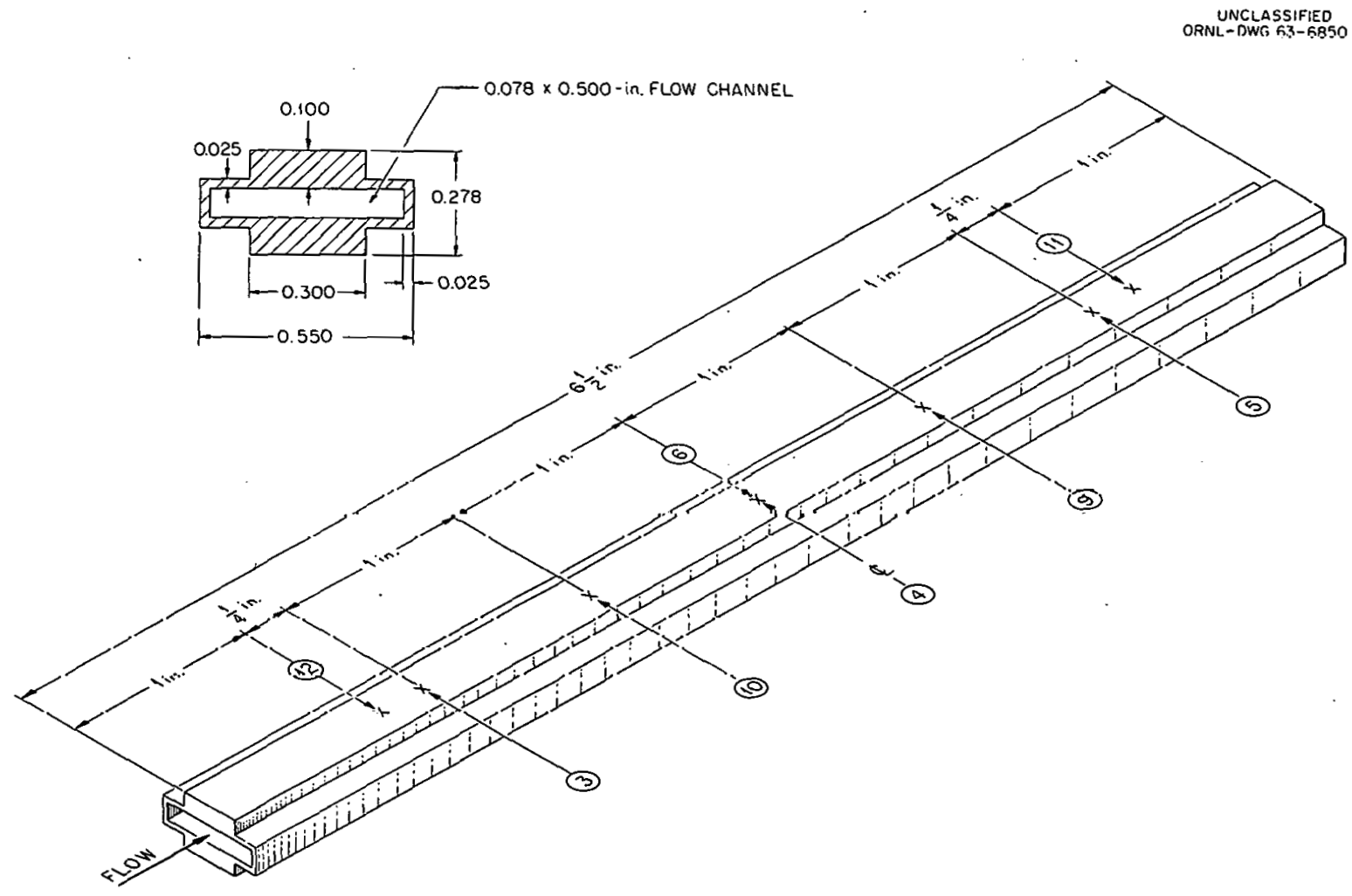

Fig. 1. Sketch of Specimen Showing Thermocouple Locotions and Cross-Sectional View.

'l'he same heat of each alloy was used in all heat-flux-corrosion tests. 'I he actual composition of the alloys (including the 1100 alloy used in past tests) is shown in Table 1 .

Heat was generated in the specimen by passage of 60-cycle ac current along the length of the specimen. The cross section of the aluminum was such that $78 \%$ of the heat was generated in the center, 0.100 -in.-thick section and $22 \%$ in the corner regions. (With a 0.050 -in.-thick channel, $80 \%$ of the heat was generated in the center section.) Considering the relative areas available for heat transfer the heat flux was 3.4 times greater across the surface under the 0.100-in.-thick region than in the corner areas. All values of heat flux given in this report refer to those across the water interface under the thicker part of the specimen. All oxide thickness and corrosion measurements were also made on the same area.

The power generated in the specimen was determined from the flow rate and the temperature increase of water passing through the central channel. The temperature increase was determined from thermocouples attached to the stainless steel pipes immediately upstream and downstream from the specimen. The flow rate was determined from the pressure drop across a calibrated orifice located in the bypass line containing the specimen.

Two different type 347 stainless steel loops were used to obtain the results discussed in this report. One was the same loop used to obtain the data already reported. ${ }^{3}$ The second was a 
Table 1. Composition of Aluminum Alloys

\begin{tabular}{lllllllll}
\hline \multirow{2}{*}{ Alloy } & \multicolumn{7}{c}{ Element (wt \%) } \\
\cline { 2 - 8 } & $\mathrm{Ni}$ & $\mathrm{Fe}$ & $\mathrm{Mg}$ & $\mathrm{Si}$ & $\mathrm{Cu}$ & $\mathrm{Cr}$ & $\mathrm{Zn}$ & A1 \\
\hline $\mathrm{X}-8001$ & 1.14 & 0.55 & & 0.03 & & & Balance \\
6061 & & 0.41 & 1.15 & 0.39 & 0.24 & 0.18 & 0.03 & Balance \\
1100 & & 0.45 & & 0.04 & 0.11 & & Balance \\
\hline
\end{tabular}

newly constructed loop utilizing the same type of components as the first except the loop piping was arranged in a slightly different manner. The first four tests in the new loop produced lower corrosion rates and lower rates of oxide buildup on the aluminum surfaces than were observed in duplicate tests conducted in the old loop. In all four cases the aluminum oxide deposit was covered with a very thin reddish-brown film which was shown by spectrographic analysis to contain mostly iron. Following these runs, the loop was treated with water containing $500 \mathrm{ppm}$ oxygen at $285^{\circ} \mathrm{C}$ for four days to develop a relatively heavy ferric-chromic oxide film on the stainless steel surface. After the high-temperature water treatment, the two loops yielded the same results and were used interchangeably; also the reddish-brown deposit was no longer found on the specimens from the new loop. A similar "new loop" effect has been reported by Draley."

During the test, the desired water quality was maintained by passing a 2- to 3-1iter/hr side stream through an ion exchange resin bed. If deionized water was the coolant, a mixed-bed deionizer (Illco-way) was used and the specific resistivity of the water during test remained at about a million ohm-cm. If the $\mathrm{pH}$ of the coolant was to be less than 7, the proper amount of nitric acid was added to the water and a cation exchanger (Amberlite IR-120) in the hydrogen form constituted the resin bed. By this method the $\mathrm{pH}$ of the coolant was maintained within $\pm 0.1 \mathrm{pH}$ unit of the desired value. The volume of each loop was 25 liters.

At the end of a test the specimen was cut from the electrodes and the edges were milled off to expose the water-cooled surfaces. In most cases three small sections were cut from each specimen, mounted in Bakelite, metallographically polished, and examined microscopically to determine the thickness of the corrosion-product layer and the type of metal attack. The depth of penetration (metal loss) was determined by measuring the thickness of each half of the specimen at several points in the transverse center before the two halves were welded together and then measuring the thickness in the same locations after removal of the corrosion product. All of the specimen except that used for metallographic examination was electrolytically descaled as described by

${ }^{7}$ J. E. Draley and W. E. Ruther, "The Corrosion of Aluminum Alloys in High Temperature Water," pp 477-95 in Conference on Corrosion of Reactor Materials, vol 1, International Atomic Energy Agency, Vienna, 1962. 
Draley. ${ }^{8}$ Although this method of determining the extent of corrosion was not highly accurate, it was the best available under the circumstances.

All procedures used for determining point heat fluxes, water interfacial temperatures, thermal conductivities, heat balance, etc. were the same as those described in a prior report. ${ }^{3}$

\section{EXPERIMENTAL RESULTS}

\section{Tests Conducted with X-8001 Aluminum}

Since the fuel elements to be used in the ATR will be subjected to somewhat higher temperatures than those in the HFIR, tests were conducted with X-8001 aluminum, an alloy more resistant to attack than either 1100 or 6061 in high-temperature water. ${ }^{9}$ Identical tests with X-8001 and 6061 were run at coolant $\mathrm{pH}$ values of 5.0 and 6.0 (adjusted with $\mathrm{HNO}_{3}$ ). In all cases the heat flux was $1.5 \times 10^{6} \mathrm{Btu} \mathrm{hr}{ }^{-1} \mathrm{ft}^{-2}$ and the flow rate was 42 to $45 \mathrm{fps}$. Figure 2 shows how the temperature at an equivalent location on each specimen increased with time. It should be noted that

\footnotetext{
${ }^{8} \mathrm{~J}$. E. Draley and W. E. Ruther, "Aqueous Corrosion of Aluminum, Part II," Corrosion 12, 480t-90t (1956).

9 J. L. English, L. Rice, and J. C. Griess, The Corrosion of Aluminum Alloys in High-Velocity Water at 170 to $290^{\circ} \mathrm{C}$, ORNL-3063 (June 1, 1961).
}

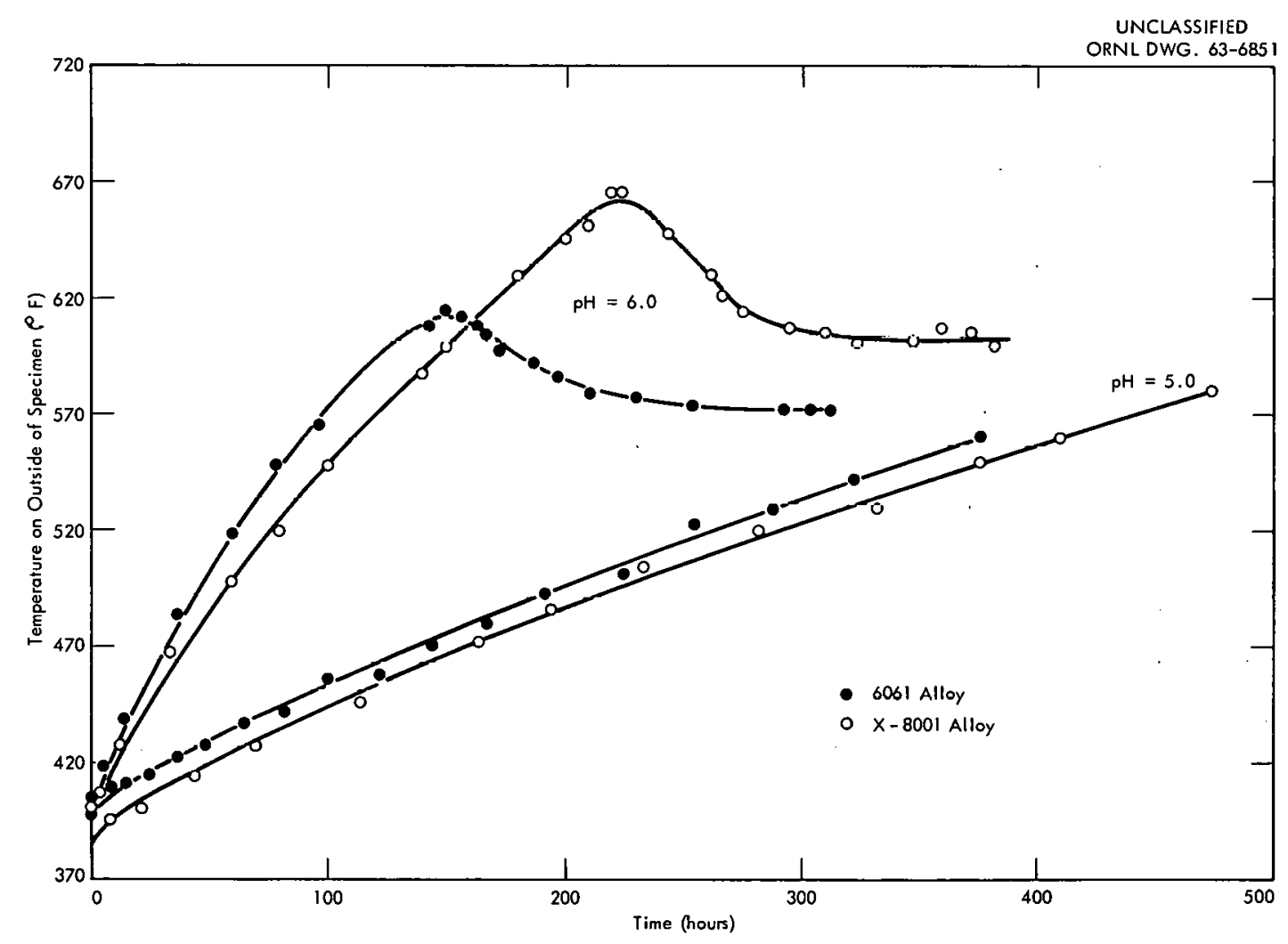

Fig. 2. Temperature Increase Observed on Aluminum Alloys Corroding at a Heat Flux of $1.5 \times 10^{6}$ Btu $\mathrm{hr}^{-1} \mathrm{ft}^{-2}$. 
the temperature increase for both alloys was much higher at a coolant $\mathrm{pH}$ of 6.0 than 5.0 , an observation in agreement with previously reported data. ${ }^{3}$

Since the operating conditions during the test were essentially constant, the increase in temperature measured on the outside of the specimen was proportional to the thickness of the corrosion product retained on the water-cooled surface. The time-temperature curves obtained at a $\mathrm{pH}$ value of 5.0 show about the same rate of oxide buildup on the 6061 and the $\mathrm{X}-8001$ specimens. At any given time the temperature of the 6061 specimen was slightly higher than that observed on the $\mathrm{X}-8001$ specimen because the thermal conductivity of the 6061 alloy is less than that of the X-8001 alloy. ${ }^{3}$ Under the conditions of these tests, the temperature drop through the 0.100 -in.-thick section was $58^{\circ} \mathrm{F}$ for 6061 aluminum and $50^{\circ} \mathrm{F}$ for $\mathrm{X}-8001$ aluminum.

At $\mathrm{pH} 6.0$ the two alloys also exhibited essentially the same behavior for the first $120 \mathrm{hr}$ of test, at which time the temperature of the 6061 specimen began to decrease. After about $210 \mathrm{hr}$ the temperature of the $\mathrm{X}-8001$ specimen also decreased. This behavior was brought about by a spontaneous spallation of part of the oxide from the specimen. No significance is attached to the fact that the X-8001 specimen reached a higher temperature than the 6061 before spallation began. It was noted in other tests that spallation usually did not occur until oxide thicknesses in the range of 2 mils had developed and that there was no way of predicting exactly when spallation would occur after that. With the 6061 specimen the temperature increase indicated that an oxide thickness of 2.2 mils formed before some oxide was lost, and with the X-8001 specimen the corresponding thickness was 2.8 mils. As indicated by the final temperatures shown in Fig. 2, a substantial amount of oxide remained on the surface after spallation.

One significant difference between the two specimens tested at $\mathrm{pH} 6.0$ was the fact that severe localized attack in the form of subsurface voids was observed on the 6061 aluminum alloy whereas very uniform attack was observed on the X-8001 alloy. In several other tests conducted at a $\mathrm{pH}$ of 5.0 with $\mathrm{X}-8001$ aluminum specimens partial film spallation was also observed after about 2 mils of oxide had formed, but in all cases only uniform and rather minor corrosion was found. On the other hand, whenever film stripping occurred with either the 6061 or the 1100 aluminum alloy, at least some localized attack of the alloy was observed.

$\mathrm{X}$-ray diffraction patterns from the oxide formed on X-8001 showed lines characteristic of only boehmite $\left(\mathrm{a}_{-} \mathrm{Al}_{2} \mathrm{O}_{3} \cdot \mathrm{H}_{2} \mathrm{O}\right)$ as was the case with the 6061 and 1100 alloys. ${ }^{3}$ Chemical analysis showed that the oxide from X-8001 specimens contained small amounts of iron and nickel, but the levels were too low to be observable in the x-ray diffraction patterns. Photomicrographs of cross sections through specimens with the oxide in place showed the oxide to be of a single phase on the 6061 and 1100 alloys; the oxide formed on X-8001 specimens contained a small amount of a metallic phase, presumed to be an iron-nickel intermetallic. Figure 3 shows photomicrographs of cross sections through 6061 and $\mathrm{X}-8001$ specimens as removed from two tests. The small particles of the metallic phase are clearly visible in the oxide on the $\mathrm{X}-8001$ specimen. 


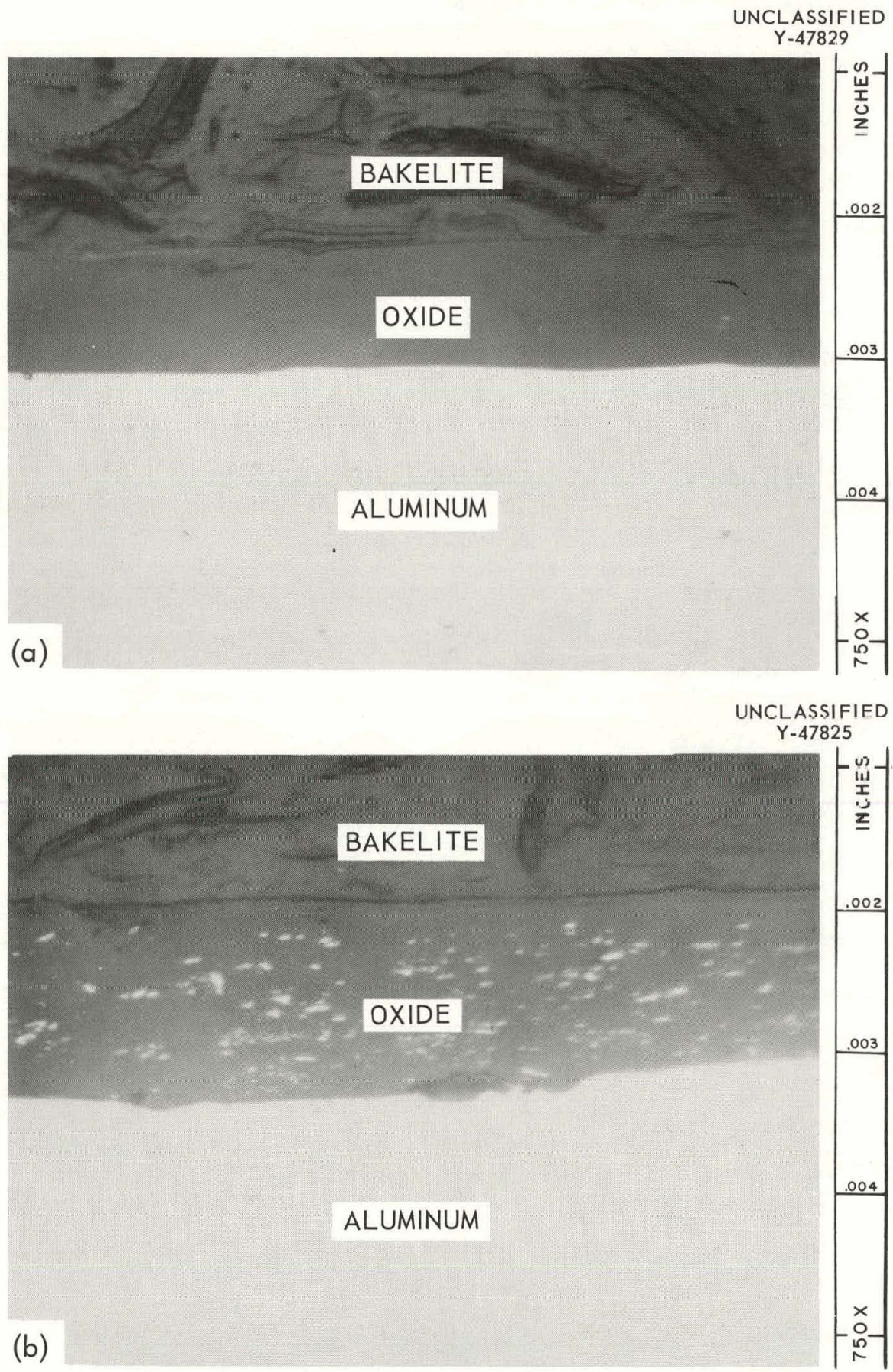

Fig. 3. Appearance of Corrosion Product on 6061 and X-8001 Aluminum Alloy Specimens. (a) 6061 aluminum alloy after exposure. Note that oxide contains only one phase. (b) X-8001 aluminum alloy after exposure. Note presence of metallic phase in oxide. 
An examination of the results from all tests showed that under comparable test conditions 1100,6061 , and X-8001 aluminum behaved the same except when film stripping or spallation occurred. In the present investigation, $X-8001$ and 6061 specimens were used interchangeably, and in correlating all the data (see later sections) no distinction was made among the three alloys.

\section{Tests Simulating an ATR Cycle}

Nuclear design calculations of the ATR core indicate that during a 17-day ATR cycle the heat flux across the aluminum fuel-element cladding will decrease as will the temperature of the coolant. To simulate this condition several tests were run in which both the coolant temperature and heat flux were periodically decreased, as shown in Fig. 4. In this figure the dotted lines show calculated changes in heat flux and coolant temperature, ${ }^{10}$ whereas the solid lines show how the two variables were actually changed during 17-day tests. Tests were conducted with nominal starting surface temperatures (specimen-water interface temperatures) of 340,360 , and $380^{\circ} \mathrm{F}$ and cuolant $\mathrm{pH}$ values of 5.0. Also two tests were conducted at $300^{\circ} \mathrm{F}$ with coolant $\mathrm{pH}$ values of 6.0 . (As discussed later, the temperature at the water interface controls the rate of oxide accumulation.) The starting surface temperature was arrived at by fixing the initial heat flux and the flow rate and adjusting the coolant temperature until the two thermocouples located on the outside of the specimen at the axial midpoint indicated the desired surface temperature plus the calculated temperature drop through the specimen wall. During the test the heat flux and coolant temperature were changed in accordance with the schedules shown in Fig. 4. In all cases the coolant velocity was $45 \mathrm{fps}$. Duplicate tests were conducted under each set of conditions, and the average temperature indicated by the two thermocouples located at the midpoint of each specimen was recorded at frequent intervals.

The results obtained with starting surface temperatures of 360 and $380^{\circ} \mathrm{F}$ are shown in Fig. 5 , and those obtained with starting temperatures of 340 and $300^{\circ} \mathrm{F}$ are shown in Fig. 6. Only the temperatures attained immediately before reducing either the bulk coolant temperature or the heat flux are plotted and straight lines connect the points.

The two tests conducted at the highest temperature agreed well when one considers that film spallation occurred on both specimens. The lower of the two curves was obtained using an X-8001 specimen, and the lower temperature at the start reflects the greater thermal conductivity of the $\mathrm{X}-8001$ alloy. As in all other cases where film spallation occurred the 6061 specimen showed localized attack whereas the $\mathrm{X}-8001$ specimen did not.

Poor agreement was observed between the duplicate runs at a starting surface temperature of $360^{\circ} \mathrm{F}$. Both specimens were 6061 aluminum and at the end of the test both were covered with a smooth, tightly adhering oxide film. Film spallation was not evident. No explanation for the poor agreement is available, and lack of time prevented running a third test under these conditions.

${ }^{10}$ Letter from G. R. Thomas, ATR Project, Babcock and Wilcox Company to G. C. Robinson, Materials Section, Babcock and Wilcox Company, Aug. 23, 1961. 


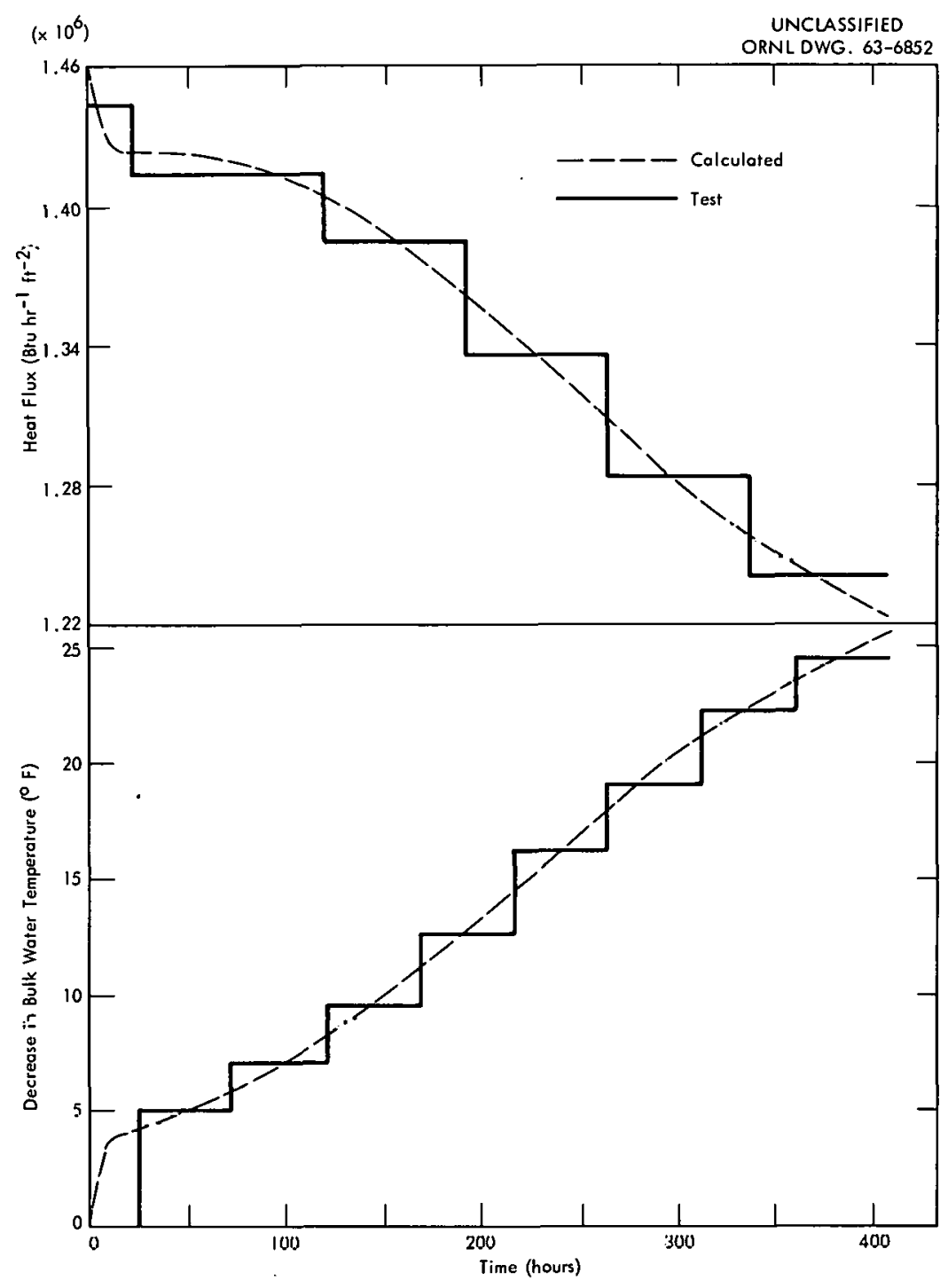

Fig. 4. Colculated Heat Flux and Coolant Temperature Change During ATR Cycle and Changes Made During Simulated Tests.

At the $340^{\circ} \mathrm{F}$ starting temperature the degree of reproducibility was not good but it was somewhat better than at $360^{\circ} \mathrm{F}$. Both specimens were made of 6061 aluminum and neither showed evidence of film spallation.

The tests at $300^{\circ} \mathrm{F}$ were conducted primarily to determine the fuel-plate temperatures that could be expected if the pH of the ATR coolant were 6.0 and fuel-element surface temperatures could be held as low as $300^{\circ} \mathrm{F}$. These two runs agreed well and indicated that if the ATR were operated with a coolant $\mathrm{pH}$ of 6.0 and if the initial surface temperature of the fuel plates were $300^{\circ} \mathrm{F}$, final fuel-element temperatures would be as high as if the starting surface temperature were $360^{\circ} \mathrm{F}$ and the $\mathrm{pH}$ were 5.0. In addition these two experiments again illustrate that there is 


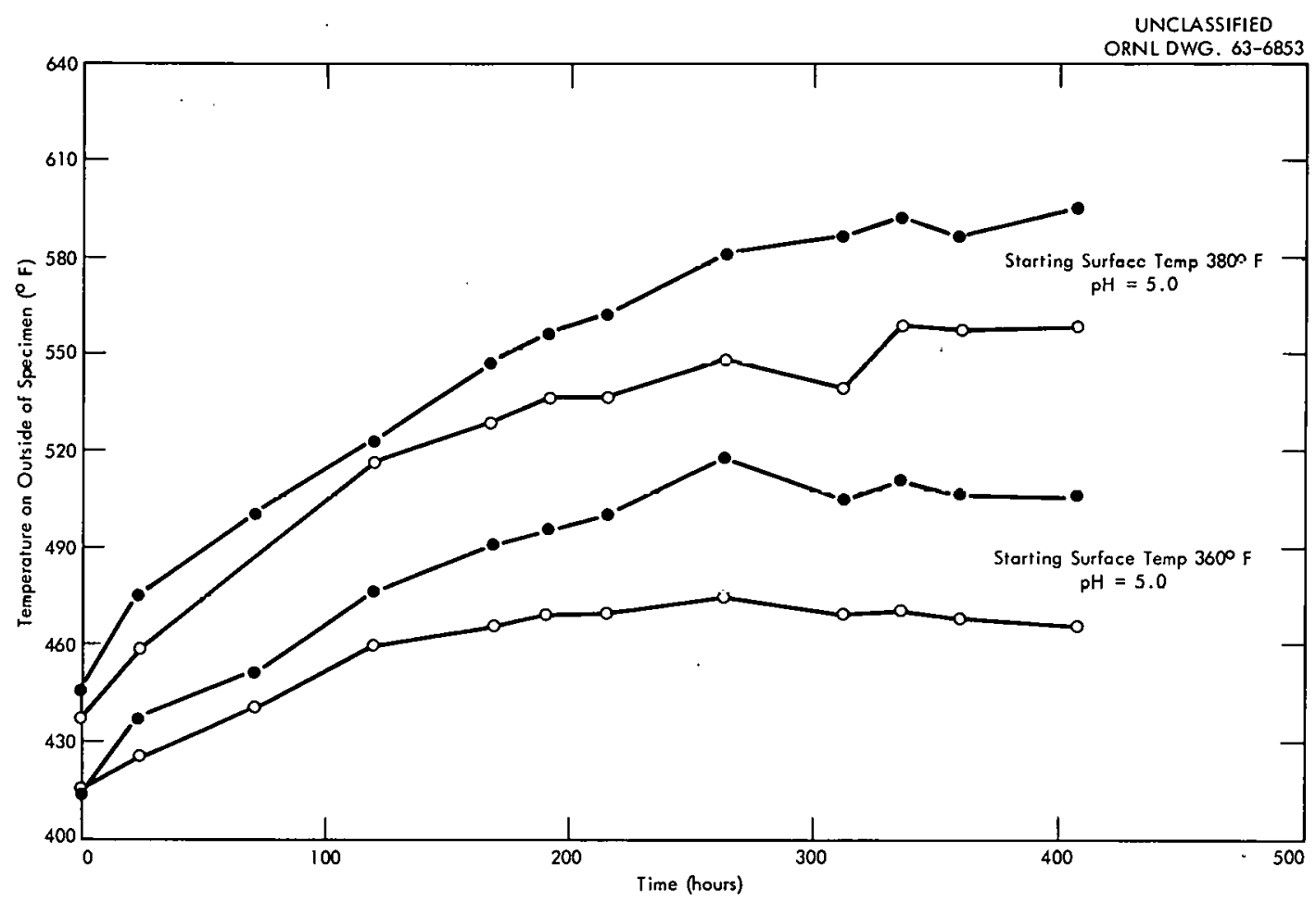

Fig. 5. Temperature of Aluminum Specimens During Tests with Decreasing Heat Flux and Coolant Temperature.

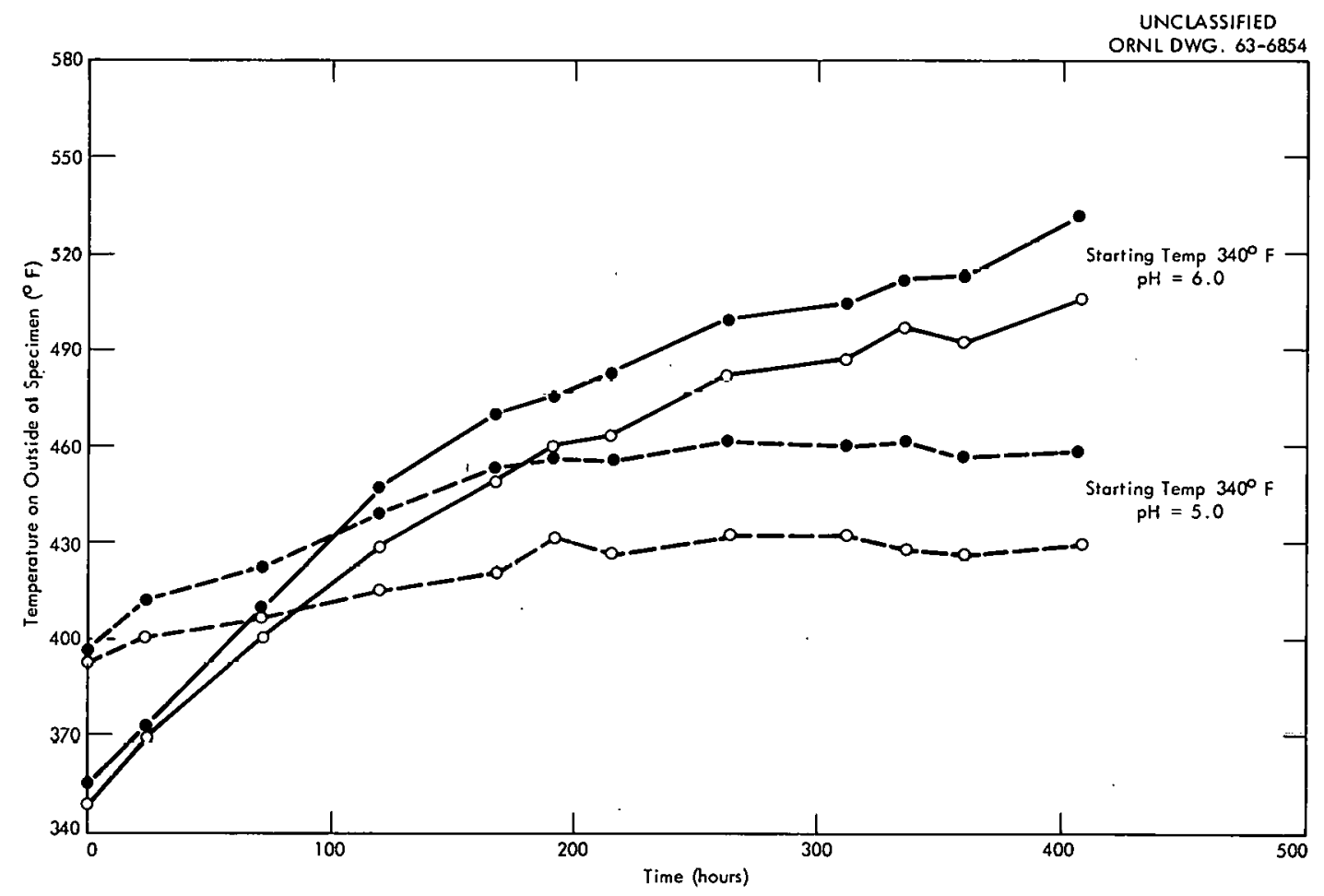

Fig. 6. Temperature of Aluminum Specimens During Tests with Decreasing Heat Flux and Coolant Temperature. 
no difference in the rate of oxide accumulation on the 6061 and X-8001 alloys when the test conditions are the same.

For the individual fuel plates to retain sufficient strength to prevent changes in plate spacings within a fuel element during a cycle, plate temperatures should not exceed about $400^{\circ} \mathrm{F}$. The results of the above series of tests show that if the $\mathrm{pH}$ of the coolant is 5.0 , starting fuel-element surface temperatures should be limited to $340^{\circ} \mathrm{F}$ or less over the major area of the fuel plates. If the $\mathrm{pH}$ of the coolant is 6.0 , unrealistically low starting surface temperatures, substantially less than $300^{\circ} \mathrm{F}$, would be necessary.

\section{Effect of Thermal Cycling on the Spalling of Oxide}

During the course of this program a tew experiments were inadvertently lnterrupled by power failures. In these cases the power was stopped instantly; and, after necessary repairs, the power usually was again supplied to the specimen instantly. It was noted that if the specimen had more than about 1 mil of oxide on its surface, some of the thermocouples frequently showed lower temperatures after the power interruption. Inspection of the surfaces of such specimens showed that as a result of the thermal cycle some of the oxide had become detached; the surface appearance indicated that small flakes of oxide had spalled randomly from the otherwise adherent oxide. On the other hand, if the corrosion product was less than about 1 mil thick, oxide was never lost during a thermal cycle; and, on resumption of power, the thermocouples indicated the same temporature as beforo the tronsient

The loss of oxide was shown to result from the heating rather than the cooling part of the cycle by the following: On several occasions when a specimen had between 1 and 2 mils of oxide on its surface, the power was cut off. The full power was then gradually restored to the specimen over a period of a few minutes rather than instantly, and in all cases temperatures along the specimen returned to the values before the power was turned off.

In all the above instances the specimen underwent a single temperature cycle. It was of interest to determine if relatively thin oxides would spall as a result of many thermal cycles. For this experiment an aluminum specimen was subjected to a heat flux of $2 \times 10^{6} \mathrm{Btu} \mathrm{hr}^{-1} \mathrm{ft}^{-2}$ and cooled with water adjusted to a $\mathrm{pH}$ of 5.0 and flowing at $45 \mathrm{fps}$. The specimen was given 30 thermal cycles after each of the following average oxide thicknesses had dcveloped (determined from temperature increase, heat flux, and thermal conductivity of oxide): $0.41,0.61,1.11$, and 1.30 mils. Each cycle consisted of turning the power on and uff as fast as possible. The first two periods of cycling (after 0.41 and $0.61 \mathrm{mil}$ ) resulted in no permanent temperature change as indicated by the thermocouples attached to the specimen. Cycling after an oxide thickness of 1.11 mils had developed resulted in one thermocouple showing a permanent temperature 1 oss of $15^{\circ} \mathrm{F}$ whereas the other six returned to their original values. When the specimen was cycled with an oxide thickness of 1.30 mils, one thermocouple, different from the one previously indicating the 
partial loss of oxide, also showed a permanent temperature loss of $18^{\circ} \mathrm{F}$ while all others returned to their original temperature.

Examination of the specimen after the test showed some small chips, roughly $1 / 32$ to $1 / 16$ in. in diameter, randomly missing from the surface of the adherent oxide. Apparently the two low thermocouple readings were caused by such chipping or spalling of the oxide on the surface immediately under the respective thermocouples.

The temperature indicated by one of the thermocouples attached to the above specimen was recorded on a Sanborn high-speed recorder to determine the rate of heating and cooling of the specimen during a thermal cycle. Figure 7 illustrates the heating and cooling rate when the oxide thickness was 1.11 mils. The total temperature change $(\Delta T)$ of about $260^{\circ} \mathrm{F}$ represents the combined temperature drop over the fluid film, oxide film, and the metal wall.

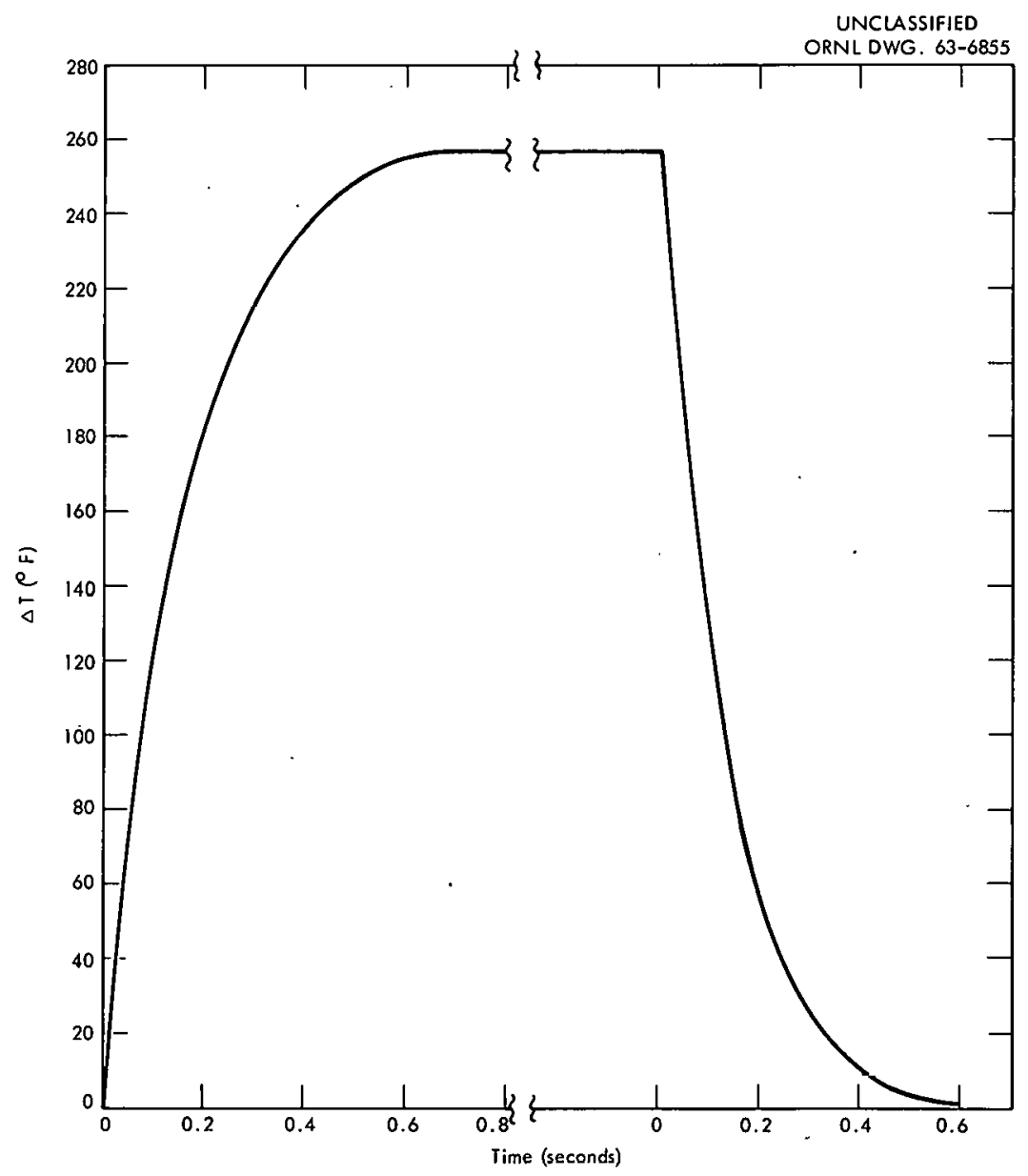

Fig. 7. Rate of Heating and Cooling of a Specimen with 1.11 mils Oxide Subjected to a Heat Flux of $2 \times 10^{6} \mathrm{Biu} \mathrm{hr}^{-1} \mathrm{ft}^{-2}$. 


\section{Effect of Pretreatment}

The effect of three different types of pretreatment on the buildup of corrosion products on aluminum specimens was investigated. One specimen was exposed to a $0.5 \%$ sodium dichromate solution at $300^{\circ} \mathrm{F}$ for $30 \mathrm{hr}$, a second specimen was "alodized," 11 and three specimens were anodized.

Both the "alodized" specimen and that treated in the sodium dichromate solution had very thin, yellowish-brown films after pretreatment. Both were tested under the following conditions: heat flux, $1.5 \times 10^{6} \mathrm{Btu} \mathrm{hr}^{-1} \mathrm{ft}^{-2}$; coolant $\mathrm{pH}, 5.0$; flow rate, $45 \mathrm{fps}$; and temperature at the specimen-water interface, $360^{\circ} \mathrm{F}$. During exposure under heat transfer conditions, the rate of temperature rise indicated by the thermocouples was essentially equal to that observed on newly machined specimens exposed under the same conditions. At the end of the tests, both specimens had developed dark uniform oxides with only an occasional faint trace of the original yellow color. Thus the results of these two tests showed that pretreatment in a dilute dichromate solution and "alodizing" produced neither a beneficial nor a detrimental effect on the rate of oxide accumulation.

The first anodized specimen was prepared locally and had an estimated oxide thickness of 0.3 mil. However in this case the two halves of the specimen were welded together before anodizing and the assumption was made that the same thickness of oxide was formed in the interior flow channel as on a flat specimen treated in the same manner. The test conditions were identical to those described above. The rate of oxide growth appeared to be unaffected by the anodized coating; essentially the same rate of temperature increase was observed as was experienced with the chromate pretreated and "alodized" specimens. In addition, cross-sectional views of the exposed specimen showed only one layer of oxide that looked identical to that formed on untreated specimens.

Two additional tests were carried out on anodized specimens. In these cases the two halves of an X-8001 and those of a 6061 specimen were anodized by the Sylcor Division of the Sylvania Electric Company to produce relatively thick, hard coatings. Before welding the halves together a small section removed from the end of one of the halves of each specimen was metaliographically mounted and polished, and the oxide thickness was measured microscopically. The thickness on the X-8001 specimen was 2.00 mils, that on the 6061 specimen was 2.84 mils.

The purpose of these two tests was to simulate conditions under which ATR test fuel plates were exposed in a lattice position in the Engineering Test Reactor (ETR). ${ }^{12}$ The anodized layer was placed on the fuel plates to cause higher temperatures than would have been possible without the insulating layer. Since the fuel plates did not contain thermocouples, it was hoped that the results of these tests, carried out under the same conditions as those in the ETR (except for radiation), would give an indication of the fuel-plate temperatures.

\footnotetext{
11 N. P. Gentieu, “Alodizing Aluminum," Industrial Finishing 23, 34-36, 40, 42, 44, 46 (1947).

12 V. A. Walker, ATR Fuel Sample Platelets, Irradiation-Experiment Design, PTR-641, July 1963.
} 
Both specimens were exposed under the same conditions: heat flux, $1.5 \times 10^{6} \mathrm{Btu} \mathrm{hr}^{-1} \mathrm{ft}^{-2}$; flow rate, 27.5 fps; coolant $\mathrm{pH}, 5.5$; and temperatures at the water interface at the specimen midpoint, $275^{\circ} \mathrm{F}$. Since there was some uncertainty about the thermal conductivity of the anodized film, it was necessary to arrive at the $275^{\circ} \mathrm{F}$ surface temperature experimentally in the following manner. A newly machined specimen (oxide free) was installed in a loop; and with the flow rate and heat flux at $27.5 \mathrm{fps}$ and $1.5 \times 10^{6} \mathrm{Btu} \mathrm{hr}^{-1} \mathrm{ft}^{-2}$, respectively, the inlet water temperature was adjusted so that the thermocouples in the middle of the specimen indicated $275^{\circ} \mathrm{F}$ plus the temperature drop through the specimen wall. Assuming a constant fluid film heat-transfer coefficient, the anodized specimens were then tested using the same inlet and outlet bulk water temperatures, which resulted in a water interfacial temperature of $275^{\circ} \mathrm{F}$ at the axial midpoint. Because of the relatively thick oxide originally on the specimens, the specimens were brought to full power gradually over a period of a few minutes to minimize the possibility of the oxide spalling.

The test with the 6061 specimen was terminated after 5 days because of an oil leak in the diaphragm of the feed pump which severely contaminated the entire system at that time. However, during the first few hours of the test it appeared that some of the oxide was lost from the surface of the specimen since temperature decreases of as much as $20^{\circ} \mathrm{F}$ were observed. Based on a thermal conductivity of $1.3 \mathrm{Btu} \mathrm{hr}^{-1} \mathrm{ft}^{-1}\left({ }^{\circ} \mathrm{F}\right)^{-1}$, the $20^{\circ} \mathrm{F}$ decrease corresponded to $0.2 \mathrm{mil}$ of oxide. For the next few days no significant temperature changes were observed. However, as the cooling water became contaminated with oil, all specimen temperatures rose sharply and the test was discontinued.

The $\mathrm{X}-8001$ specimen was exposed in the loop for 19 days. During this time the average temperature of the specimen increased slowly as shown in Fig. 8 for three different thermocouple locations. The middle curve represents the temperature at the specimen midpoint where the water interfacial temperature was calculated to be $275^{\circ} \mathrm{F}$. The corresponding surface temperatures for the other two curves were $286^{\circ} \mathrm{F}$ for the upper curve and $270^{\circ} \mathrm{F}$ for the lower one. The peculiar shape of the curves was probably caused by slight fluctuations in heat flux. Because of the thick coating on the specimen, the calculated temperature drop across the aluminum wall and oxide [assuming 2.00 mils of oxide with a thermal conductivity of $1.3 \mathrm{Btu} \mathrm{hr}^{-1} \mathrm{ft}^{-1}\left({ }^{\circ} \mathrm{F}\right)^{-1}$ ] was $240^{\circ} \mathrm{F}$ at a heat flux of $1.5 \times 10^{6} \mathrm{Btu} \mathrm{hr}^{-1} \mathrm{ft}^{-2}$. Thus even a $\pm 2 \%$ variation in the electrical power supply to the specimen (directly proportional to heat flux) would produce a spread of $10^{\circ} \mathrm{F}$ which could account for the irregularities in the curves.

The indicated temperature increases from the beginning to the end of the test were 58,49 , and $41^{\circ} \mathrm{F}$ for the upper, middle, and lower curves respectively. With a heat flux of $1.5 \times 10^{6} \mathrm{Btu} \mathrm{hr}^{-1}$ $\mathrm{ft}^{-2}$ and an assumed thermal conductivity of the oxidc of $1.3 \mathrm{Btu} \mathrm{hr}^{-1} \mathrm{ft}^{-1}\left({ }^{\circ} \mathrm{F}\right)^{-1}$, the temperature increases correspond to increases in oxide thickness of $0.60,0.51$, and $0.43 \mathrm{mil}$ at the three locations. The measured oxide thickness increases at the same locations were $0.95,0.88$, and 0.67 mil. Perhaps some of the poor agreement between the measured and calculated thicknesses, in addition to that possibly caused by slight variations in power input, may have resulted from a change in the anodized film as a result of the test exposure. Figure 9 shows a cross section of 


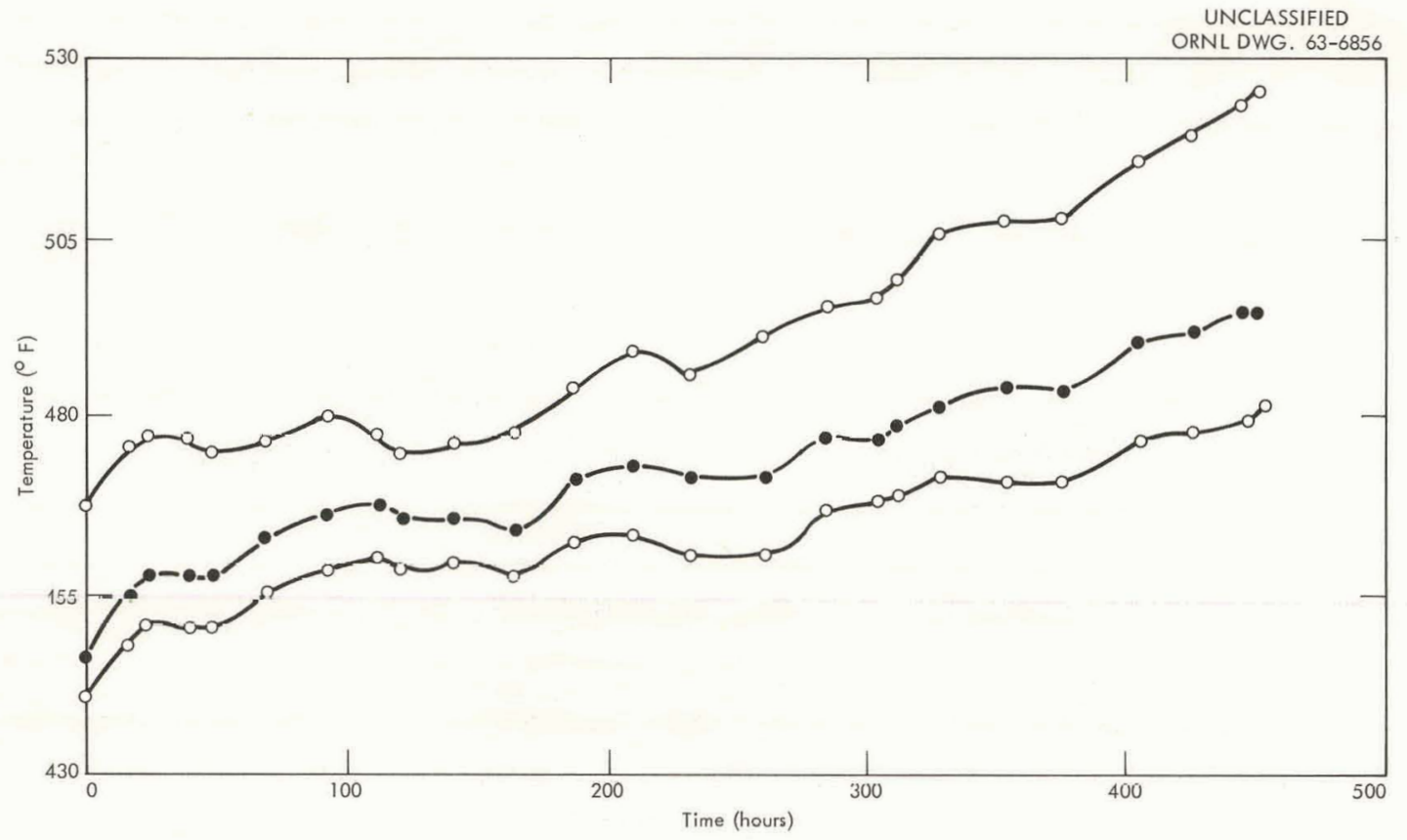

Fig. 8. Temperature at Three Locations on an X-8001 Aluminum Alloy Specimen Which Had Been Anodized to Produce a 2-mil-thick Oxide Coating Before Test.

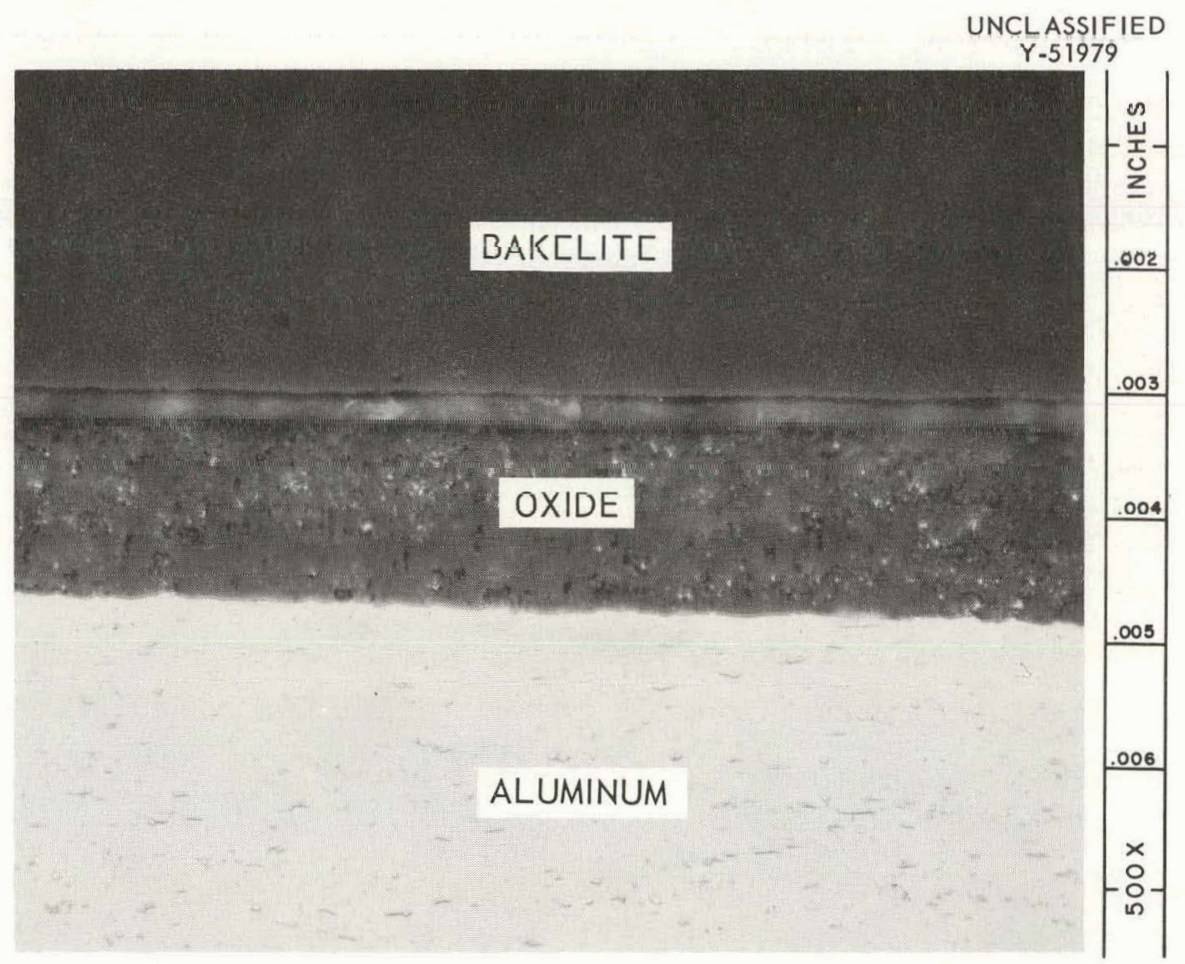

Fig. 9. Cross-Sectional View of X-8001 Specimen Before Test Showing Anodized Film. Note the two distinct layers in film. 
the oxide before the test, and Fig. 10 shows a similar cross section taken from the middle of the specimen at the conclusion of the test. The original oxide was composed of two distinct layers. After exposure the oxide still appeared to contain two layers but there was no sharp interface between them. It is possible that during the test the thermal conductivity of the original anodized film increased and caused the calculated oxide thickness (based on temperature increase) to be less than actually observed. The possibility that such occurred was indicated by examination of the oxide on the specimens after exposure. The initial surfaces were very hard; after the test the surfaces were relatively soft, and the oxide could easily be removed by light scraping with a sharp object. Prior to exposure a reflection electron diffraction pattern indicated only an amorphous product on the surface. After the test a similar pattern indicated boehmite, which was the corrosion product found on all untreated specimens.

If the 19-day test conducted out-of-pile was representative of the ETR exposure, the temperature of the in-pile fuel plates at the aluminum-aluminum oxide interface was $395^{\circ} \mathrm{F}$ at the start of the cycle and $444^{\circ} \mathrm{F}$ after 19 days. No evidence of localized attack was observed on the X-8001 test specimen. The results of the ETR test program have not been reported at this time.

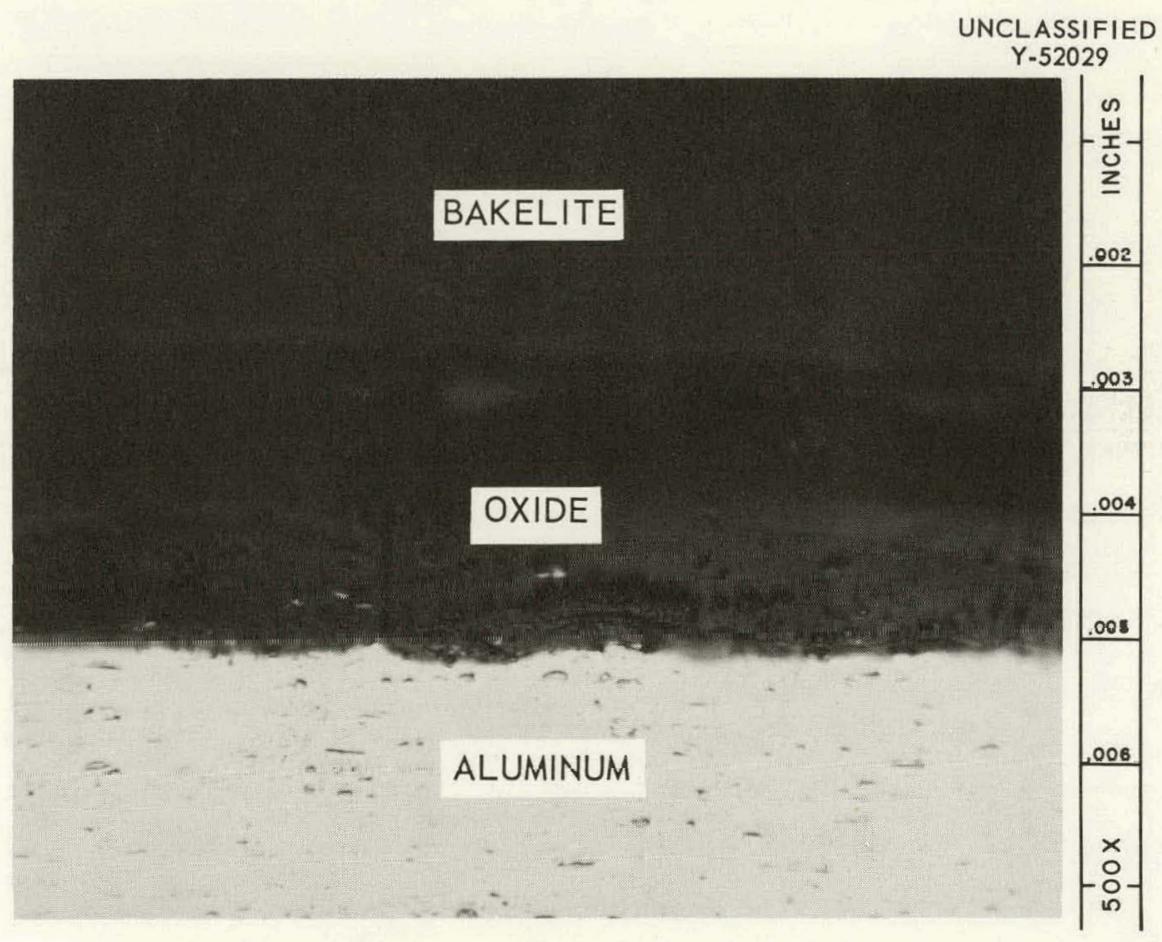

Fig. 10. Cross-Sectional View of Same Specimen Shown in Fig. 9 After Test. Note changes in appearance of axide as a result of test. 


\section{Thermal Conductivity of Corrosion Product Film}

Additional measurements of the thermal conductivity of the corrosion product (boehmite) were made using the procedure previously described. ${ }^{3}$ As was reported, the average value of the thermal conductivity derived from 56 sets of data was $1.5 \mathrm{Btu} \mathrm{hr}^{-1} \mathrm{ft}^{-1}\left({ }^{\circ} \mathrm{F}\right)^{-1}$ with a standard deviation of \pm 0.4 . In 21 of the 56 cases the temperature drop across the oxide film equalled or exceeded the temperature drop across the fluid film, a condition which improves the accuracy of the determination. Considering the 21 sets as being the most reliable, a value of $1.3 \mathrm{Btu} \mathrm{hr}^{-1} \mathrm{ft}^{-1}\left({ }^{\circ} \mathrm{F}\right)^{-1}$ with a standard deviation of \pm 0.2 was obtained.

Since the above data were reported, an additional 80 measurements of the thermal conductivity of the oxide were made. Of this number, 59 measurements were made under conditions where the temperature drop across the oxide equalled or exceeded that across the fluid film. Thus a total of 136 measurements were made, 80 of which were made under the most favordble cundiliuns. The average value of the thermal conductivity considering all determinations was $1.4 \mathrm{Btu} \mathrm{hr}^{-1} \mathrm{ft}^{-1}$ $\left({ }^{\circ} \mathrm{F}\right)^{-1}$ with a standard deviation of \pm 0.3 . The average value for the 80 selected determinations was $1.3 \mathrm{Btu} \mathrm{hr}^{-1} \mathrm{ft}^{-1}\left({ }^{\circ} \mathrm{F}\right)^{-1}$ with a standard deviation of \pm 0.2 .

The additional measurements confirm the value of the thermal conductivity of the corrosion product determined earlier. As was noted at that time the value of the thermal conductivity was independent of temperature, heat flux, $\mathrm{pH}$ of coolant, and alloy on which the oxide formed within the ranges investigated. The same conclusion applies to the present data.

\section{Effect of Time and Temperature on Oxide Formation}

It was reported previously that under constant conditions the specimen temperature increased approximately linearly with exposure time, and the data were treated in that manner. ${ }^{3}$ The abovc conclusion was based on tests of short duration, usually about 10 days, at relatively low temperatures. Tests conducted for the ATR frequently lasted longer and for the most part were carried out at higher surface temperatures. The results of these tests clearly indicated that the oxide did not accumulate at a constant rate but that the rate decreased with exposure time. Reexamination of the results from all tests indicate that the data are best described by an equation of the form

$$
T-T_{0}=\Delta T=m \theta^{p},
$$

where $T_{0}$ is the temperature indicated by a thermocouple at the start of the test, $T$ is the temperature at the same location at time $\theta$, and $m$ and $p$ are constants. The data acquired from the individual thermocouple readings in all runs in which the conditions were held constant and where film spallation did not occur were analyzed by the least-squares method to determine the value of $p$. From 270 separate sets of data the average value of $p$ was 0.76 with a standard deviation of 0.06 . For reasons to be discussed later, a better value of $p$ appears to be 0.778 . 
The value of $p$ was independent of heat flux, $\mathrm{pH}$, or temperature. This fact is illustrated in Fig. 11 where the temperatures indicated by one thermocouple from several runs made under different conditions are plotted vs time to the 0.778 power. In each case a straight line fits the data points well.

The value of the proportionality constant, $m$, as determined from $\Delta T$ 's and exposure times was dependent on temperature, $\mathrm{pH}$, and to a lesser extent on heat flux. The fact that the individual temperature-(time) ${ }^{0.778}$ curves were of constant slope even though the temperature at the metalmetal oxide interface increased very substantially indicated that the controlling temperature was that at the water interface which was essentially constant during most runs.

An approximately linear relation existed between the log of $m$ (normalized to a common heat flux and obtained at a fixed $\mathrm{pH}$ ) and the reciprocal of the absolute temperature at the specimenwater interface when heat fluxes were in the range of 1 to $2 \times 10^{6} \mathrm{Btu} \mathrm{hr}^{-1} \mathrm{ft}^{-2}$ (see Fig. 12). The water interfacial temperature was determined at the beginning of a run by assuming no oxide on the specimen at that time and subtracting the temperature drop through the wall from the thermocouple reading at that point. The temperature drop through the wall was calculated from the point heat flux and thermal conductivity. Since all conditions remained constant during a given run, it was assumed that the water interfacial temperature also remained constant.

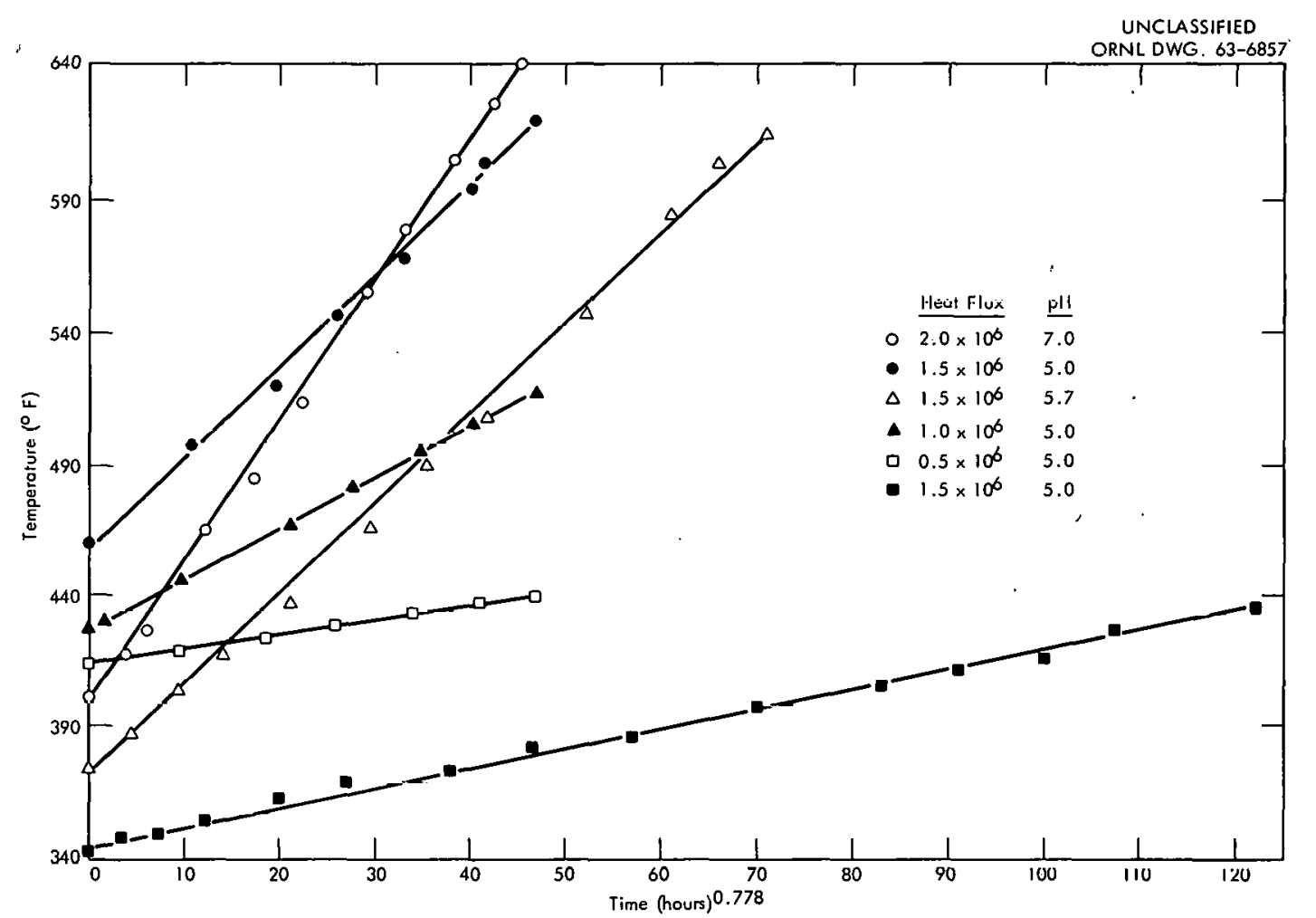

Fig. 11. Examples of Lineor Relation Between Specimen Temperature and Exposed Time to the 0.778 Power. 


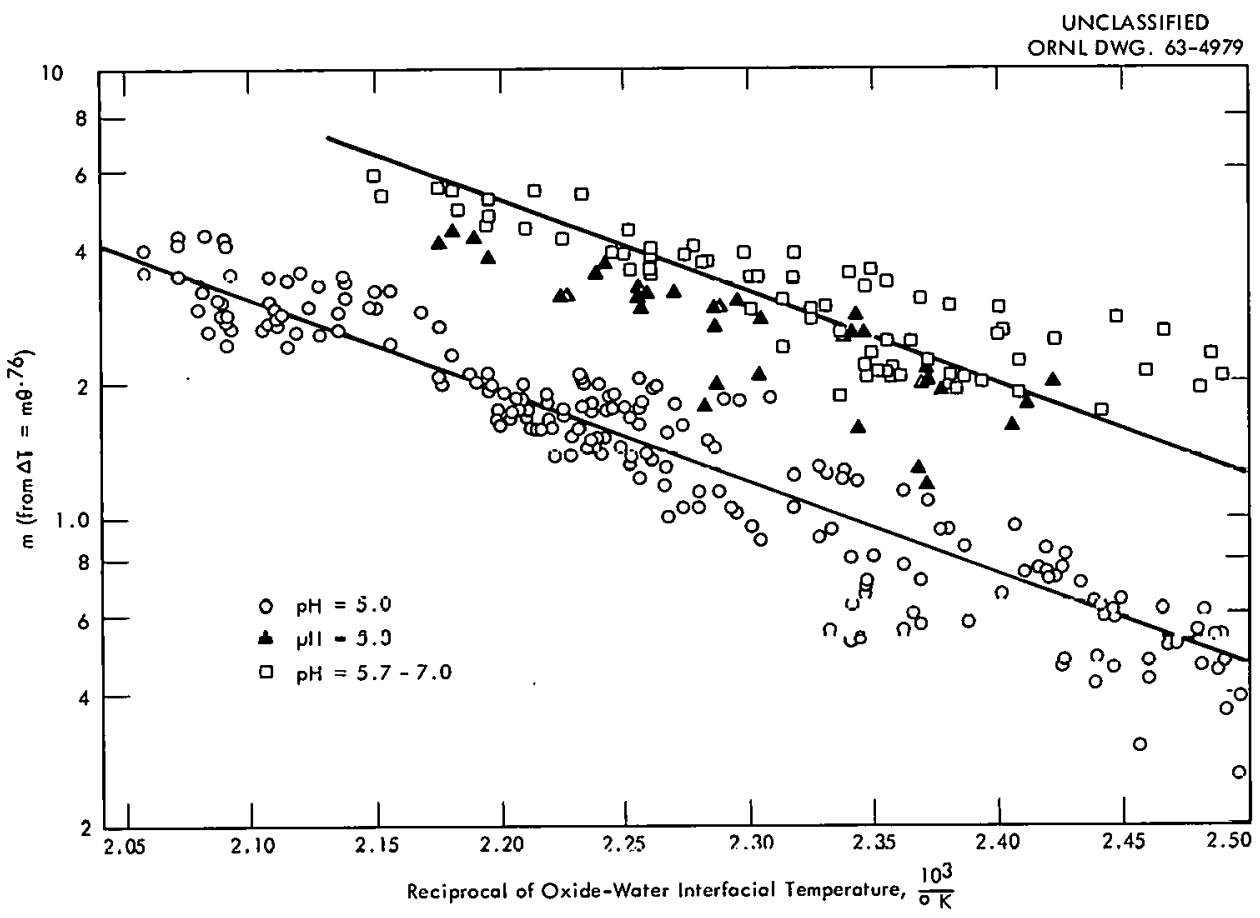

Fig. 12. Rate of Temperoture Rise of Aluminum Test Specimens Corroding at Heat Fluxes Between 1 and $2 \times 10^{6} \mathrm{Btu} \mathrm{hr}^{-1} \mathrm{ft}^{-2}$. All values have been normalized to $1.5 \times 10^{6} \mathrm{Btu} \mathrm{hr}^{-1} \mathrm{ft}^{-2}$.

The above correlations ( $\Delta T$ with timo and $m$ with temperature) provide a convenient way of extrapolating the data and of illustrating the effect of variables on oxide formation.

\section{Effect of Heat Transfer Rate}

Since this program was conducted to determine the extent of corrosion and corrosion-product buildup on ATR and HFIR fuel plates under the most severe conditions, heat fluxes in the range of 1 to $2 \times 10^{6} \mathrm{Btu} \mathrm{hr}^{-1} \mathrm{ft}^{-2}$ were employed in most tests. It was reported previously ${ }^{3}$ that in this range heat flux per se did not appear to be a significant variable although only a very few tests were conducted with heat fluxes other than $1.5 \times 10^{6} \mathrm{Btu} \mathrm{hr}^{-1} \mathrm{ft}^{-2}$. The data indicated that the rate of oxide accumulation was a function of the temperature at the specimen-water interface and the $\mathrm{pH}$ of the coolant.

In order to extend the investigation of the effect of heat flux additional tests were conducted. In this series of tests the coolant $\mathrm{pH}$ and flow rate were maintained at 5.0 and $45 \mathrm{fps}$ respectively. The temperature of the coolant was constant in any one run but was changed from run to run so that the temperature at the specimen-water interface at the axial midpoint of the specimen was $(403 \pm 4)^{\circ} \mathrm{F}$ regardless of heat flux. All tests except two lasted for $142 \mathrm{hr}$. At the end of the tests the specimens were sectioned across the midpoint and the oxide thicknesses were measured. Table 2 shows the results. 
The two runs at the highest heat flux were inadvertently stopped too soon. However by extrapolating the times to $142 \mathrm{hr}$, an oxide thickness of 1.65 mils would have been expected in the first case and 1.27 mils in the second. With the exception of the value of 1.65 , the results indicate no significant effect of heat flux in the range 1 to $2 \times 10^{6} \mathrm{Btu} \mathrm{hr}^{-1} \mathrm{ft}^{-2}$ so long as the temperature at the specimen-water interface was constant. The data show, however, that significantly lower oxide thicknesses developed at the 0.7 and $0.5 \times 10^{6} \mathrm{Btu} \mathrm{hr}^{-1} \mathrm{ft}^{-2}$. level than at higher heat fluxes.

Table 2. The Effect of Heat Flux on the

Formotion of Corrosion Product

on Aluminum ${ }^{a}$

\begin{tabular}{cc}
\hline $\begin{array}{c}\text { Heat Flux } \\
\left(\text { Btu } \mathrm{hr}^{-1} \mathrm{ft}^{-2}\right)\end{array}$ & $\begin{array}{c}\text { Oxide Thickness } \\
\text { (mils) }\end{array}$ \\
\hline$\times 10^{6}$ & \\
1.94 & $1.16^{b}$ \\
1.92 & $0.84^{c}$ \\
1.47 & 1.28 \\
0.99 & 1.36 \\
0.70 & 1.15 \\
0.51 & 0.75 \\
0.48 & 0.75 \\
\hline
\end{tabular}

\footnotetext{
${ }^{a}$ In all tests coolant flow rate and $\mathrm{pH}$ were $45 \mathrm{fps}$ and 5.0 , the specimen-water interfacial temperature was $403^{\circ} \mathrm{F}$, and except in two cases the exposure time was $142 \mathrm{hr}$.

${ }^{b}$ Test lasted $92 \mathrm{hr}$.

c Test lasted $84 \mathrm{hr}$.
}

\section{Effect of $\mathrm{pH}$}

One of the most important variables in determining the extent of corrosion and the rate of oxide accumulation on aluminum surfaces was the $\mathrm{pH}$ of the coolant. Qualitative data showing this fact were presented in two earlier reports. ${ }^{3,13}$ Additional experiments combined with the use of the correlation presented in a previous section have resulted in a clearer picture of the effect of $\mathrm{pH}$ than previously existed.

${ }^{13} \mathrm{~J}$. C. Griess et al., Effect of Heat Flux on the Corrosion of Aluminum by Water. Part II. Influence of Water Temperature, Velocity and pH on Cortosion Product Formation, ORNL-3056 (Feb. 10, 1961). 
In addition to the many tests conducted with the coolant at a $\mathrm{pH}$ of 5.0 , several tests were conducted in deionized water and in water with the $\mathrm{pH}$ adjusted to $5.3,5.7$, or 6.0 with nitric acid. Using only those tests in which the heat flux was between 1 and $2 \times 10^{6} \mathrm{Btu} \mathrm{hr}^{-1} \mathrm{ft}^{-2}$, the value of the proportionality constant, $m$, was determined by dividing the temperature rise indicated by each thermocouple by the exposure time to the 0.76 power. In those cases where oxide spallation occurred or where the conditions were changed during the run, only the data acquired before change or spallation were used. Figure 12 shows a plot of the $\log$ of $m$ vs the reciprocal of the absolute temperature at the specimen-water interface. Since the temperature rise was directly proportional to heat flux, all $\mathrm{m}$ values were normalized to a common heat flux of $1.5 \times 10^{6} \mathrm{Btu} \mathrm{hr}^{-1}$ $\mathrm{ft}^{-2}$.

The data points generally fall into two groups. Those scattered around the lower curve were obtained when the $\mathrm{pH}$ of the coolant was $5.0 \pm 0.1$; those around the upper curve, which was drawn parallel to the lower one, were obtained at all higher $\mathrm{pH}$ values. There was no discernible difference among the data obtained when the $\mathrm{pH}$ was in the range of 5.7 to 7.0. Most of the data points derived from the tests in which the $\mathrm{pH}$ was 5.3 fall close to the upper curve but are generally below it.

Although there is considerable scatter of the points around the line drawn through the pH 5.0 data, there is little doubt that a straight line relation exists between the $\log$ of $m$ and the reciprocal of the absolute temperature. When one considers that the tests from which the data were derived were conducted over a 3 -yr period in two different loops the fit of the points to the line is satıšfáctory.

The scatter of the points around the upper curve is comparable to that around the lower curve. Perhaps another straight line of slightly different slope would describe the data better than the line shown; however, considering that there are fewer data points on this curve and that the runs were usually of short duration before film spallation began, drawing the line parallel to that at the lower $\mathrm{pH}$ appeared reasonable. If one accepts the lines as drawn to be correct, Fig. 12 shows that the rate of oxide buildup is 2.7 times greater in the $\mathrm{pH}$ range of 5.7 to 7.0 than at a $\mathrm{pH}$ of 5.0 .

Only two brief tests were completed in which the $\mathrm{pH}$ of the coolant was 4.7 . In both cases the flow rate was $45 \mathrm{fps}$ and the heat flux was $1.5 \times 10^{6} \mathrm{Btu} \mathrm{hr}^{-1} \mathrm{ft}^{-2}$. In one case the water-specimen interfacial temperatures were in the range of $330^{\circ} \mathrm{F}$ and in the other, $400^{\circ} \mathrm{F}$. In both cases calculated $m$ values were such that when plotted as were the other data the individual points (not shown in Fig. 12) all fell within the scatter band of the lower curve, indicating the same rate of oxide growth at a $\mathrm{pH}$ of 4.7 as at $\mathbf{5 . 0}$.

Three separate tests were conducted to determine how the rate of temperature rise changed when the $\mathrm{pH}$ of the coolant was changed during a run. In two of the tests the $\mathrm{pH}$ of the coolant was 5.0 at the start of the run, after some period was changed to 6.0 , and later was changed back to 5.0. In the other case the initial $\mathrm{pH}$ of the coolant was 6.0 which was changed to 5.0 and later back to 6.0. In all three runs other operating conditions were held constant during each run.

In all three tests the temperature-(time) ${ }^{0.778}$ curves obtained at all thermocouple locations showed abrupt changes in slope when the $\mathrm{pH}$ was changed. This is illustrated in Fig. 13 which 


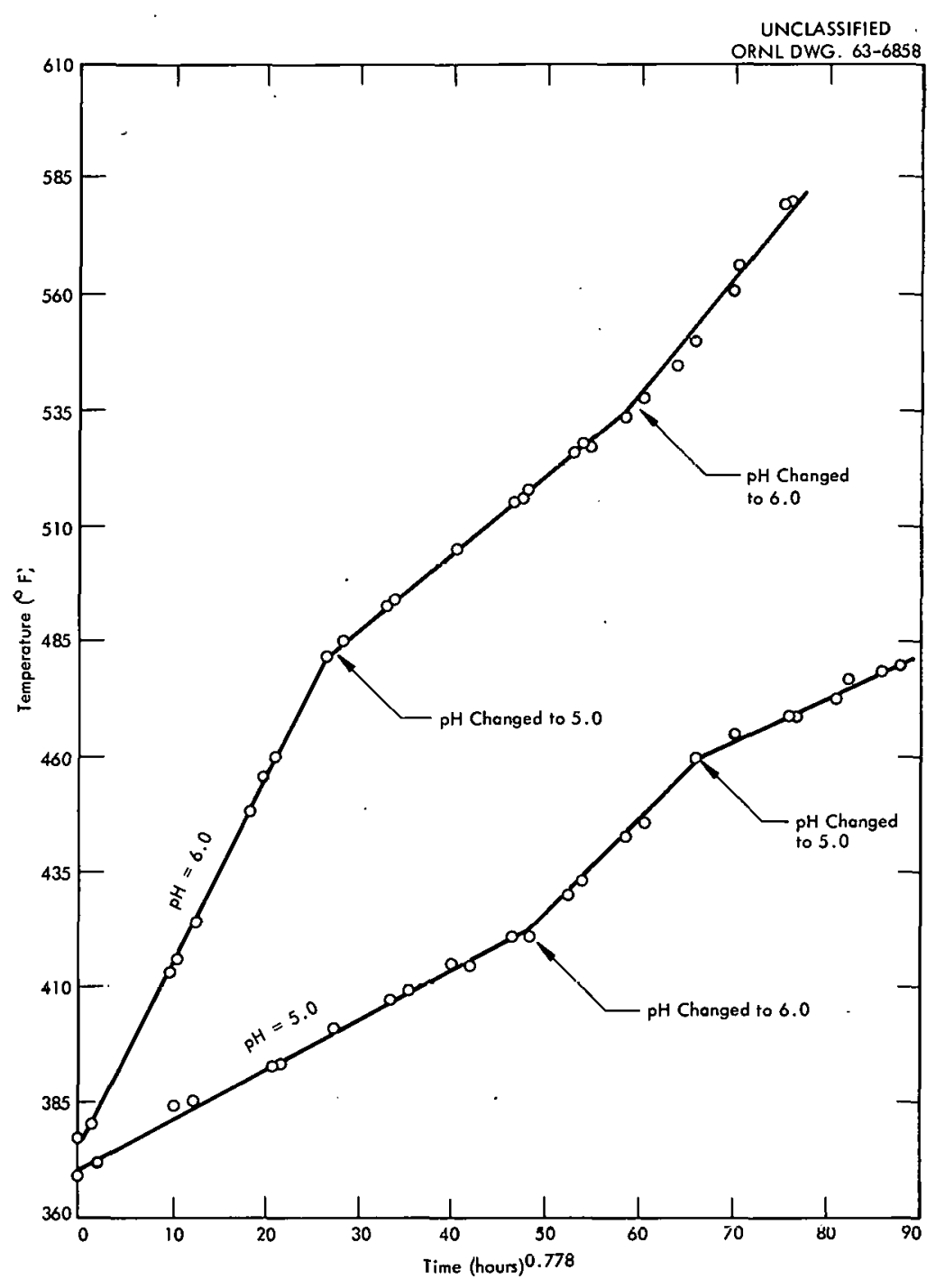

Fig. 13. Effect of Changing pH on the Shape of Time-Temperature Curves.

shows two typical curves, one with a starting $\mathrm{pH}$ of 5.0 and the other with a starting $\mathrm{pH}$ of 6.0 . The change in slope upon changing the $\mathrm{pH}$ is clearly evident.

\section{Effect of Flow Rote}

Since in both the ATR and the HFIR the flow rate of the coolant past the fuel plates will be 40 to $45 \mathrm{fps}$, most testing was carried out in that velocity range. However one test was conducted at a flow rate of $25 \mathrm{fps}$ and another at $33 \mathrm{fps}$. In both cases the results were in agreement with those obtained at the higher flow rates under otherwise comparable conditions; that is, the rate of oxide formation was the same as observed at higher flow rates. 
Thus the data indicate that in the range of 25 to $45 \mathrm{fps}$, flow rate is not an important variable in determining the rate of oxide buildup. Similar observations concerning the effect of velocity on the corrosion of aluminum in isothermal tests have been made at other installations. ${ }^{14}$

\section{Correlation of Oxide Buildup with Exposure Time and Temperature}

The ability of the empirical equation

$$
\Delta T=m \theta^{p}
$$

to describe the experimental time-temperature relation has already been demonstrated. Furthermore it is evident from Fig. 12 that in the heat-flux range of 1 to $2 \times 10^{6} \mathrm{Btu} \mathrm{hr}^{-1} \mathrm{ft}^{-2}$ and at a fixed $\mathrm{pH}$, the value of $m$ depends on the temperature at the water interface in the following manner:

$$
m=a \exp \left(\frac{-b}{K}\right),
$$

where $a$ and $b$ are constants and $K$ is the absolute temperature. Substituting in the first equation,

$$
\Delta T=a \theta^{p} \exp \left(\frac{-b}{K}\right) .
$$

Since the temperature increase is proportional to the oxide thickness (at constant heat flux), it follows that

$$
X=a \theta^{p} \exp \left(\frac{-b}{k}\right),
$$

where $X$ is the oxide thickness and the value of the constant $a$ is different from that in the preceding equation.

Using the above model and 83 separate sets of data obtained al a $\mathrm{pH}$ of 5.0 each of which involved an oxide thickness measurement and a known surface temperature and cxposure time, the best values of $a, p$, and $b$ were determined by a linear regression analysis. The values of $a, p$, and $b$ calculated by this means were $443,0.778$, and 4600 with $X$ expressed in mils, $\theta$ in hours, and temperature in degrees Kelvin. With the Rankine temperature scale, the value of $b$ is 8290 . Figure 14 which is a plot of measured oxide thickness vs oxide thickness calculated from the equation indicates that the correlation is generally satisfactory.

To compute confidence limits for $X$, one needs the variance of $X$ which is a function not only of the variances and covariances of the estimates of $a, p$, and $b$ but also of the values of $\theta$ and $K$ for which the prediction of $X$ is desired. Table 3 gives estimates of oxide thicknesses at the $95 \%$ confidence limits at several exposure times and temperatures.

It should be emphasized that the above correlation is valid only when the $\mathrm{pH}$ of the coolant is 5.0 and heat flux is in the range of 1 to $2 \times 10^{6} \mathrm{Btu} \mathrm{hr}^{-1} \mathrm{ft}^{-2}$. It has been noted that at heat

\footnotetext{
${ }^{14}$ R. J. Lobsinger, Summary Report on the Corrosion of Aluminum in High Temperature Dynamic Water Systems, HW-59778 REV (Feb. 1, 1961).
} 


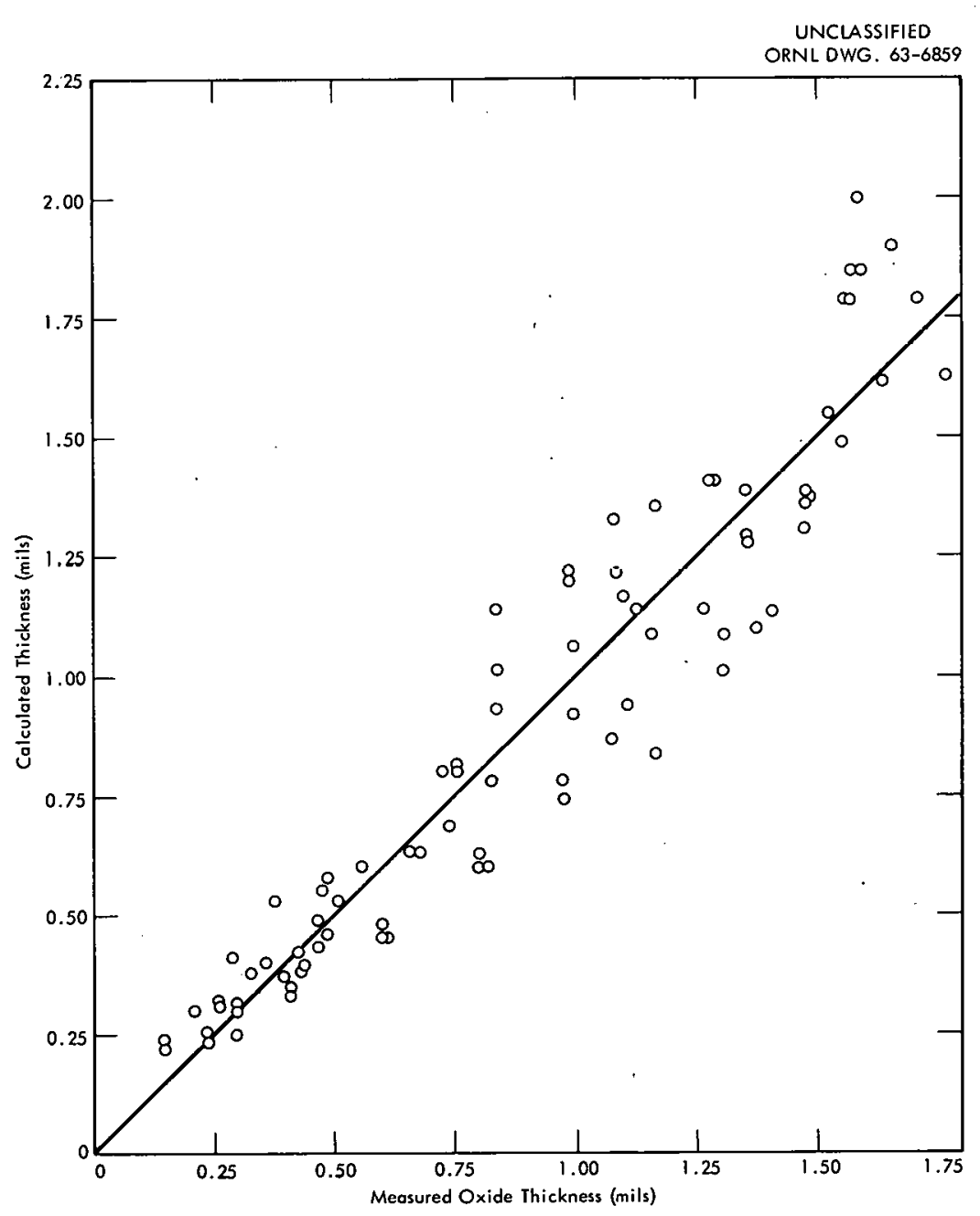

Fig. 14. Comparison of Measured and Calculated Oxide Thicknesses.

fluxes less than $1 \times 10^{6} \mathrm{Btu} \mathrm{hr}^{-1} \mathrm{ft}^{-2}$ lower rates of oxide formation are observed than predicted by the equation (see Table 2).

Insufficient oxide thickness measurements were made on specimens exposed at $\mathrm{pH}$ values greater than 5.0 to obtain a meaningful analysis by the above means. However noting that the oxide formed in proportion to the same exponential power of the exposure time as at a $\mathrm{pH}$ of 5.0 and that the temperature dependence was independent of $\mathrm{pH}$, it follows that the same relation describing the data at a $\mathrm{pH}$ of 5.0 is applicable except that the initial coefficient should be 2.7 times greater than at $\mathrm{pH}$ of 5.0 . Hence in the $\mathrm{pH}$ range of 5.7 to 7.0 the equation should be

$$
X=1200 \theta^{0.778} \exp \left(\frac{-4600}{K}\right) \text {. }
$$

To calculate the total oxide accumulated under conditions where the water-oxide interfacial temperature changes, as during a reactor cycle (see Fig. 4), one must proceed as follows. The 
Table 3. Predicted Oxide Thicknesses and Upper and Lower Limits at the $95 \%$ Confidence Level

\begin{tabular}{ccccc}
\hline $\begin{array}{c}\text { Surface } \\
\text { Temperature } \\
(\mathrm{F})\end{array}$ & $\begin{array}{c}\text { Time } \\
(\mathrm{hr})\end{array}$ & $\begin{array}{c}\text { Lower } \\
\text { Limit } \\
\text { (mils) }\end{array}$ & $\begin{array}{c}\text { Predicted } \\
\text { Thickness } \\
\text { (mils) }\end{array}$ & $\begin{array}{c}\text { Upper } \\
\text { Limit } \\
\text { (mils) }\end{array}$ \\
\hline \multirow{2}{*}{250} & 100 & 0.117 & 0.135 & 0.154 \\
& 200 & 0.212 & 0.231 & 0.252 \\
& 300 & 0.294 & 0.316 & 0.340 \\
300 & 400 & 0.367 & 0.395 & 0.426 \\
& 100 & 0.262 & 0.290 & 0.523 \\
& 200 & 0.473 & 0.497 & 0.713 \\
& 300 & 0.652 & 0.682 & 0.904 \\
& 400 & 0.805 & 0.853 & 0.024 \\
& 100 & 0.322 & 0.305 & 1.022 \\
& 200 & 0.932 & 0.976 & 1.414 \\
& 300 & 1.265 & 1.337 & 1.804 \\
& 400 & 1.552 & 1.673 & 1.127 \\
& 100 & 0.945 & 1.032 & 1.898 \\
& 200 & 1.649 & 1.769 & 2.642 \\
& 300 & 2.227 & 2.426 & 3.367 \\
\hline
\end{tabular}

oxide formed during the interval at the first temperature is calculated directly from the equation. The oxide formed during the first and second intervals is calculated using in the equation the time that would have been required to produce the oxide formed during the first interval had it been at the second temperature plus the time actually at the second temperature. For all subsequent temperature intervals a similar procedure must be used. This is illustrated in Fig. 15 where the dotted lines $T_{1}, T_{2}$, and $T_{3}$ represent the rate of oxide buildup at three different temperatures and the solid lines represent oxide growth as the surface temperature is changed from $T_{1}$ to $T_{2}$ to $T_{3}$. The $\theta$ 's shown on the graph in Fig. 15 must be converted to time when used in the equations.

The adequacy of the above procedure for calculating oxide thickness when the surface temperature is changed is illustrated in Figs. 16 and 17. Figure 16 represents a run in which the heat flux, flow rate, and coolant $\mathrm{pH}$ were held constant at $1.5 \times 10^{6} \mathrm{Btu} \mathrm{hr}^{-1} \mathrm{ft}^{-2}, 45 \mathrm{fps}$, and 5.0 , respectively, but the coolant temperature was twice increased by $50^{\circ} \mathrm{F}$ during the run. The surface temperatures were, in order, $300^{\circ} \mathrm{F}, 350^{\circ} \mathrm{F}$, and $400^{\circ} \mathrm{F}$. The initial temperature of $300^{\circ} \mathrm{F}$ was determined by subtracting the wall drop from the thermocouple reading at that location. The subsequent surface temperatures were obtained by adding the increase in bulk water temperature to the original temperature, a procedure that assumed no change in fluid film coefficient. In Fig. 16 the solid line represents the calculated temperature increase $(\Delta T)$ as a function of time whereas the points are actual experimental data. The calculated oxide thicknesses were converted to 


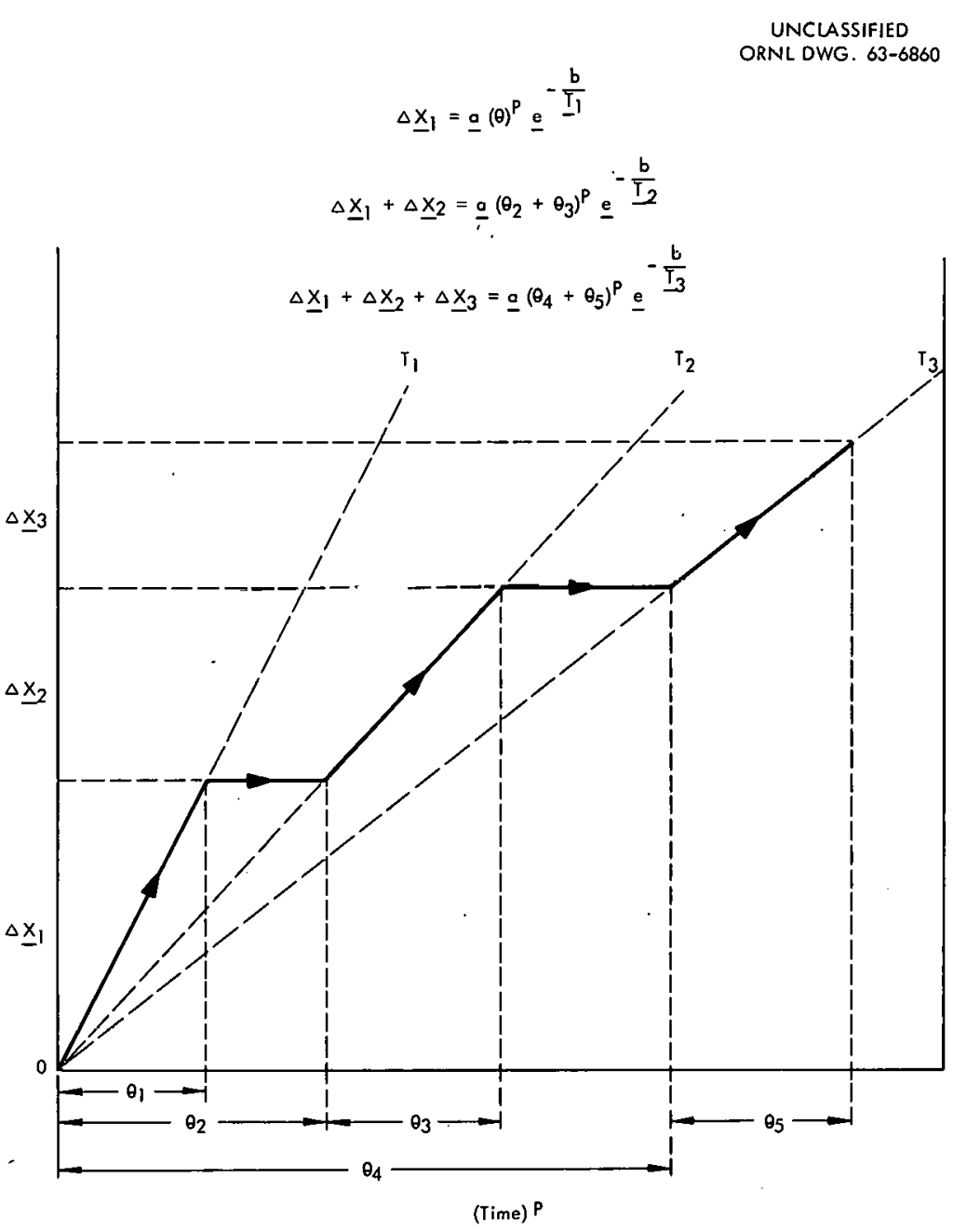

Fig. 15. Schematie Representation of Oxide Growth as Temperature Is Changed.

$\Delta T$ values from the equation

$$
\Delta T=\frac{Q X}{k}
$$

where $Q$ is heat flux, $X$ is oxide thickness, and $k$ is thermal conductivity of the oxide. ${ }^{15}$ The agreement between the calculated and experimental $\Delta T$ values is within the expected range (see Fig. 12 and Table 3).

Figure 17 represents a run in which both the heat flux and coolant temperature were changed several times during the run according to the schedule shown in Fig. 4. The flow rate and $\mathrm{pH}$ were held constant at $45 \mathrm{fps}$ and 5.0 respectively. The calculations were carried out in the above

\footnotetext{
${ }^{15}$ W. H. McAdams, Heat Transmission, p 13, MoGraw-Ilill, New Yurk, 1954.
} 


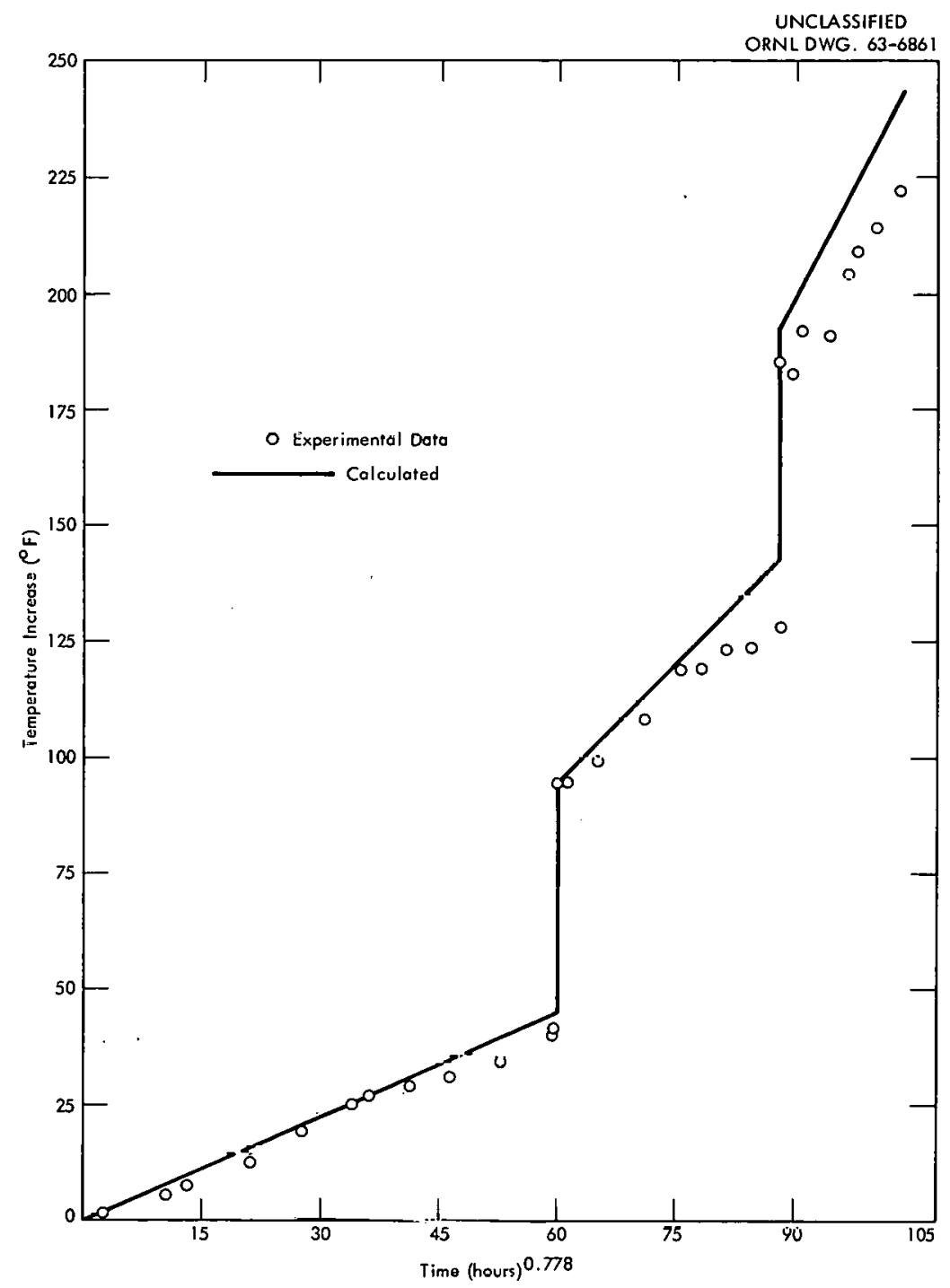

Fig. 16. Comparison of Calculated and Experimentally Determined Temperature Increases.

manner by personnel at Babcock and Wilcox ${ }^{16}$ using only the actual starting surface temperature and the schedule shown in Fig. 4 as a basis for calculation. The solid circles represent the experimentally determined temperatures immediately before a change in heat flux or coolant temperature and the open circles represent the corresponding calculated temperatures. As in the first example, the agreement between calculation and experiment is satisfactory.

\footnotetext{
1963.

16 Private communication from G. C. Robinson, Babcock and Wilcox Company to J. C. Griess, July 1 ,
(963.
} 


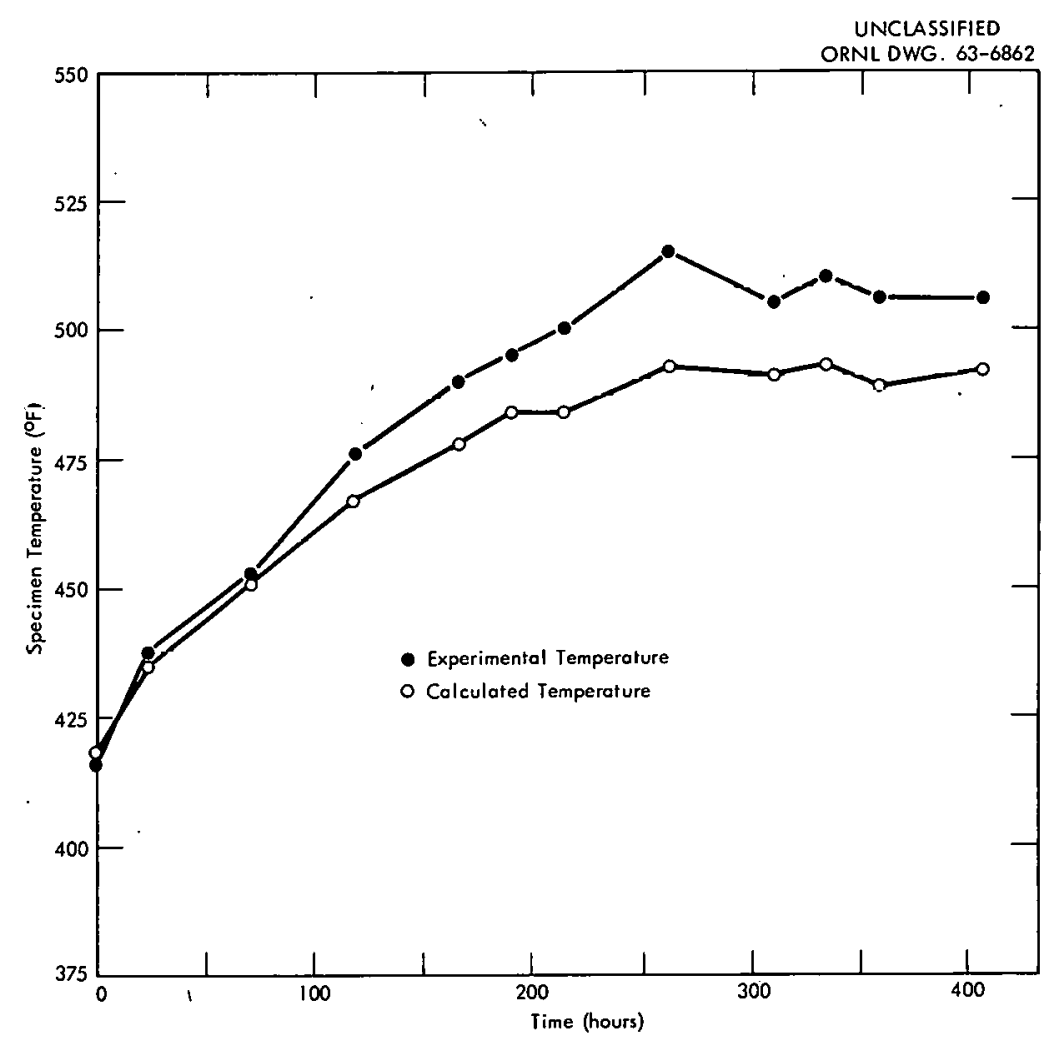

Fig. 17. Comparison of Calculated and Experimentally Determined Temperatures from a Test in Which Heat Flux and Coolant Temperature were Changed Several Times.

\section{Corrosion}

As indicated previously the extent of corrosion was determined as the difference between the original wall thickness and the wall thickness at the end of the test (after removal of the corrosion product). This methud liad the inherent disadvantage of relying on a small difference between two relatively large numbers to determine corrosion penetration, and consequently the determinations were not highly accurate. In addition there was always the possibility that during assembly or disassembly of the specimen the soft aluminum surface could be deformed or scratched which would lead to further inaccuracies.

In spite of the ahove disadvantages all tcat specimens were measured before and after the test to determine total uniform penetration. The maximum uniform penetration observed on any specimen was 2.4 mils when the $\mathrm{pH}$ of the coolant was 5.0. This value was obtained with an $\mathrm{X}-8001$ specimen exposed under the following conditions: heat flux, $1.5 \times 10^{6} \mathrm{Btu} \mathrm{hr}^{-1} \mathrm{ft}^{-2}$; flow rate, $45 \mathrm{fps}$; average temperature at specimen-water interface, $360^{\circ} \mathrm{F}$; and time, $737 \mathrm{hr}$. These conditions were comparable to those expected to exist in parts of the ATR except for the exposure time 
which was almost twice the length of a fuel cycle. In all other tests conducted at a $\mathrm{pH}$ of 5.0, penetrations were less than 2 mils. Thus the corrosion data indicate that uniform corrosion penetration of the aluminum fuel-element cladding (10 mils) is highly unlikely if the $\mathrm{pH}$ of the coolant is maintained at 5.0 .

When the $\mathrm{pH}$ of the coolant was 5.7 to 7.0 , the deepest penetration observed in this investigation was that which occurred on the 6061 specimen whose temperature behavior is shown in Fig. 2 . The $\mathrm{pH}$ of the coolant was 6.0 and the test lasted for $315 \mathrm{hr}$. In this case, uniform penetration amounted to 2 to $3 \mathrm{mils}$ and localized penetration extended into the metal an additional 2 to 3 mils. This observation combined with previously reported data ${ }^{3}$ lead to the cunclusion that penctration of either 6061 or 1100 cladding at hot spots is a distinct possibility in both the ATR and the HFIR at the $\mathrm{pH}$ levels much above 5.0 . With the $\mathrm{X}-8001$ alloy penetration of the clad would probably not occur, but the fast rate of oxide buildup at the higher $\mathrm{pH}$ levels would result in excessive fuelplate temperatures.

In cases where film spallation did not occur, only very uniform corrosion was observed (see Fig. 3 for example); there was never any evidence of pitting or other kinds of localized attack. Under the same conditions the extent of corrosion as well as the rate of corrosion-product buildup was the same for all three alloys. When oxide films became so thick that spallation occurred, the 6061 and 1100 alloy specimens always suffered localized attack in the form of subsurface voids as illustrated in Fig. 18. The depth of the localized attack depended on the duration of test after film stripping started. In contrast to the 1100 and 6061 alloys, the X-8001 alloy corroded uniformly even in those cases where extensive film spallation occurred.

Since the depth of metal corroded depended on micrometer measurements, the relation of this penetration to the thickness of oxide on the specimen at the end of the test could not be determined with high precision. However, in general the ratiu of the uxide thickncss (measured metallographically) to the depth of uniform metal penetration was about 1.4 for all runs in which film stripping did not occur. Furthermore the value of this ratio appeared to be indcpendent of $\mathrm{pH}$. The average value of the ratio was 1.45 for the runs in which the $\mathrm{pH}$ was 5.0 and 1.38 for the runs in which the $\mathrm{pH}$ was 5.3 or higher. In both cases the spread in the individual ratios was large, a fact which reflects the uncertainty in the determination of the metal loss. Unfortunately no useful data were obtained when the $\mathrm{pH}$ of the coolant was 4.7. The outside surfaces of both specimens were scratched during assembly or disassembly, and measurements of the amount of metal corroded were meaningless. However, based on the fact that the rate of oxide accumulation was the same as at a $\mathrm{pH}$ of 5.0 , it is probable that the relation between oxide buildup and corrosion penetration was the same at the two $\mathrm{pH}$ values.

The results generally indicate that the greater the corrosion the greater the thickness of oxide on the aluminum at the end of the test, regardless of $\mathrm{pH}$. Thus as a first approximation the equation that related oxide thickness to exposure time and temperature could be used to estimate the extent of uniform corrosion. On the average, the depth of corrosion penetration was about $70 \%$ of the oxide thickness. Obviously this relation is not valid when oxide spallation occurs. 


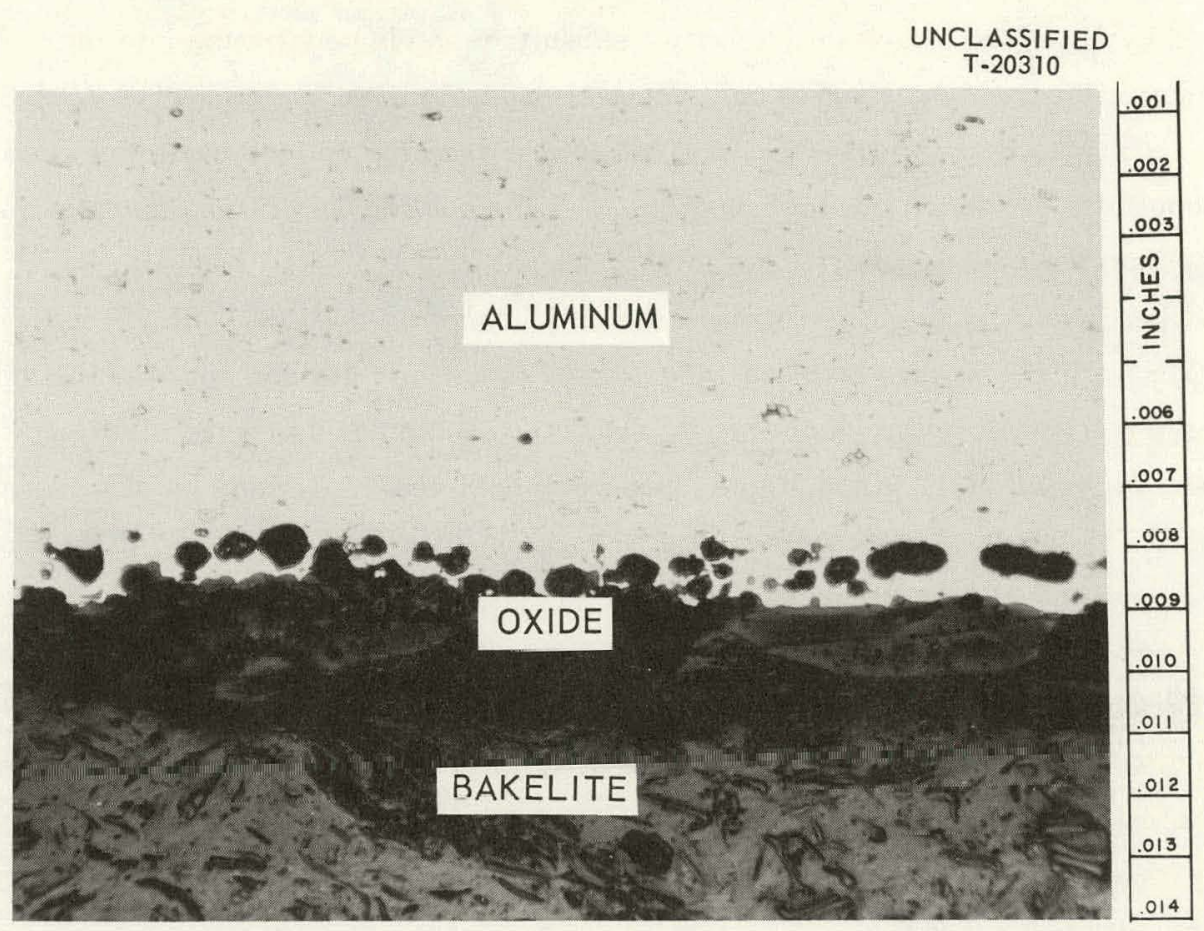

Fig. 18. Localized Attack of a 6061 Aluminum Alloy Specimen. Note voids below corroding surface.

If the ratio of oxide thickness to metal penetration is taken to be 1.4 and if the density of the corrosion product is $3.02 \mathrm{~g} / \mathrm{cm}^{3}$ as reported by Ervin and Osborn for boehmite, ${ }^{17}$ it can be shown that about $70 \%$ of the aluminum that corroded remained on the specimen as an adherent corrosive product and $30 \%$ was lost to the coolant.

\section{CONCLUSION AND SUMMARY}

The results of the corrosiun lests under conditions of high heat flux conducted at ORNL indicate that any of the three aluminum alloys investigated, 1100,6061 , and X-8001, has adequate corrosion resistance to be used as cladding material for the ATR and HFIR fuel plates, provided the $\mathrm{pH}$ of the cooling water is adjusted to 5.0 with nitric acid. The maximum penetration observed under more stringent conditions than expected to exist during the operation of either reactor was 2.4 mils which is less than $25 \%$ of the minimum design cladding thickness for either reactor. In deionized water, and even at $\mathrm{pH}$ values only slightly above 5.3 , the corrosion of aluminum was 2.7 times greater than at 5.0 and under these conditions the failure of $1100-$ or 6061 -clad fuel elements is much more likely. After corrosion-product films about 2 mils thick developed, spontaneous spallation of corrosion product from all three alloys was probable and spallation was always

\footnotetext{
${ }^{17}$ G. Ervin, Jr., and E. F. Osborn, “The System $\mathrm{Al}_{2} \mathrm{O}_{3}-\mathrm{H}_{2} \mathrm{O}, " J$. Geology 59, 381-94 (1951)
} 
accompanied by localized attack in the form of subsurface voids penetrating into the 6061 and 1100 aluminum alloys; only uniform attack, however, was observed on the X-8001 alloy regardless of the test conditions or the degree of film spallation. Since the corrosion-product thickness is directly proportional to corrosion, lowering the $\mathrm{pH}$ of the cooling water to 5.0 substantially lessens the likelihood of clad failure.

If corrosion damage of the cladding were the only concern, the X-8001 alloy would be preferred over the other two. However in addition to the direct effect of corrosion damage, the indirect effect, that is the formation of an insulating layer of corrosion products on the aluminum surface which causes high fuel-plate temperatures, must be considered. As corrosion of a fuel plate proceeds the plate temperature increases and its mechanical strength decreases. If the plate is unable to withstand the forces acting on it, deformation and partial blockage of a coolant channel could occur and burnout of part of the fuel plates is possible. Therefore the increase in fuel-plate temperatures resulting from the formation of a corrosion-product layer must be considered carefully in the design of the fuel elements. Based on the results of this experimental program and the mechanical properties study of Martin and Weir ${ }^{4}$ only the 6061 alloy has adequate creep resistance to be used as fuel-plate cladding if the $\mathrm{pH}$ of the coolant is 5.0; with the cooling water at a higher $\mathrm{pH}$, even the 6061 alloy would be inadequate.

It is concluded from this investigation that the 6061 aluminum alloy will be a satisfactory cladding material for both the ATR and HFIR fuel elements. Under the expected operating conditions, penetration of the clad by corrosion is very improbable assuming no adverse effects of radiation. The long-term successful use of aluminum-clad fuel elements in the Materials Test Reactor and the Engineering Test Reactor indicates such an assumpliun is justifled.

A summary of the major experimental results obtained during the course of this program is given below:

1. Three aluminum alloys $(1100,6061$, and $\mathrm{X}-8001)$ were subjected to corrosion tests under conditions where the heat transfer rate across the corroding surfaces was in the range of 0.5 to $2 \times 10^{6} \mathrm{Btu} \mathrm{hr}^{-1} \mathrm{ft}^{-2}$. Under the same exposure conditions all alloys corroded to the same extent until corrosion-product films thick enough to spall spontaneously had developed (in the range of 2 mils). After spallation the 1100 and 6061 alloys always showed localized attack of the aluminum, whereas the X-8001 alloy showed only very uniform attack under all conditions.

2: The rate at which an insulating layer of corrosion product accumulated on the watercooled surfaces was the same for all alloys and was independent of coolant flow rate in the range of 25 to $45 \mathrm{fps}$.

3. The thermal conductivity of the corrosion-product layer (boehmite) was determined to be 1.3 Btu hr ${ }^{-1} \mathrm{ft}^{-1}\left({ }^{\circ} \mathrm{F}\right)^{-1}$ with a standard deviation of \pm 0.2 .

4. The rate at which oxide built up on a specimen was dependent on $\mathrm{pH}$. Other conditions being the same, oxide formed 2.7 times faster when the $\mathrm{pH}$ of the coolant was 5.7 to 7.0 than when the $\mathrm{pH}$ was 5.0. At a $\mathrm{pH}$ of 5.3 the rate appeared to be only slightly less than at higher pH's. Based on only two brief tests, the rate at a $\mathrm{pH}$ of 4.7 was the same as at 5.0. 
5. Temperature was an important variable in determining the rate of oxide formation. The controlling temperature was that at the aluminum oxide-water interface (surface temperature).

6. Heat flux in the range of 1 to $2 \times 10^{6} \mathrm{Btu} \mathrm{hr}^{-1} \mathrm{ft}^{-2}$ was not a significant variable; essentially the same rate of oxide buildup was observed in this range so long as the surface temperature and $\mathrm{pH}$ were the same. On the other hand, heat flux was important in the range of 0.5 to $1 \times$ $10^{6} \mathrm{Btu} \mathrm{hr}^{-1} \mathrm{ft}^{-2}$. At $0.5 \times 10^{6} \mathrm{Btu} \mathrm{hr}^{-1} \mathrm{ft}^{-2}$ the rate of oxide formation was about half that observed at heat fluxes of 1 to $2 \times 10^{6} \mathrm{Btu} \mathrm{hr}^{-1} \mathrm{ft}^{-2}$, other conditions being the same.

7. Under constant operating conditions, oxide accumulated on the test specimens in proportion to exposure time to the 0.778 power. This relation existed regardless of heat flux, $\mathrm{pH}$, flow rate, or surface temperature.

8. The proportionality constant relating oxide thickness and exposure time to the $\mathbf{0 . 7 7 8}$ power was dependent on $\mathrm{pH}$ and surface temperature and to a lesser extent on heat flux. At a fixed $\mathrm{pH}$ a plot of the log of the proportionality constant (actually rate constant since it was obtained by dividing oxide thickness by time to the 0.778 power) vs the reciprocal of the absolute temperature yielded a straight line.

9. The oxide formed on test specimens was related to exposure time and temperature by an equation of the form

$$
X=a \theta^{p} \exp \left(-\frac{b}{K}\right)
$$

where $X$ is thickness, $\theta$ is time, $K$ is surface temperature, and $a, p$, and $b$ are constants. Considering only the data obtained in the heat flux range of 1 to $2 \times 10^{6} \mathrm{Btu} \mathrm{hr}^{-1} \mathrm{ft}^{-2}$ and with the coolant at a pH of 5.0, the best values of $a, p$, and $b$ were determined by a linear regression analysis to be $443,0.778$, and 4600 , respectively, when thickness is expressed in mils, time in hours, and temperature in degrees Kelvin. Under the same conditions except with the coolant $\mathrm{pH}$ in the range of 5.7 to 7.0, all constants were the same except the constant a which was 1200 instead of 443. In both $\mathrm{pH}$ ranges the above correlation predicted oxide thicknesses considerably higher than were observed when the heat flux was less than $1 \times 10^{6} \mathrm{Btu} \mathrm{hr}^{-1} \mathrm{ft}^{-2}$.

10. The extent of corrosion was closely related to the thickness of oxide on the surface. As a first approximation the extent of uniform corrosion was about $70 \%$ of the oxide thickness regardless of $\mathrm{pH}$, heat flux, or surface temperature so long as film stripping did not occur. Thus the correlation given above can be used to estimate corrosive penetration of the aluminum. 


\section{THIS PAGE}

\section{WAS INTENTIONALLY LEFT BLANK}


1. Biology Library

2-4. Central Research Library

5. ORNL - Y-12 Technical Library, Document Reference Section

6. Reactor Division

7-41. Laboratory Records Department

42. Laboratory Records ORNL R.C.

43. R. J. Beaver

44. E. G. Bohlmann

45. G. E. Boyd

46. R. D. Cheverton

47. E. L. Compere

48. J. E. Cunningham

49. J. L. English

50. L. G. Farrar

51-61. J. C. Griess

62. W. R. Grimes

63. Neil Hilvety

64. L. B. Holland

65. J. E. Lee, Jr.
66. A. L. Lotts

67. G. H. Jenks

68. C. E. Larson

69. D. L. McElroy

70. J. R. McGuffey

71. H. A. McLain

72. J. R. McWherter

73. M. M. Martin

74. R. B. Parker

75. S. A. Rabin

76. S. A. Reid

77. A. E. Richt

78. H. C. Savage

79. J. L. Scott

80. M. J. Skinner

81. A. M. Weinberg

82. J. H. Westsik

83. F. Daniels (consultant)

84. F. T. Gucker (consultant)

85. E. A. Mason (consultant)

\section{EXTERNAL DISTRIBUTION}

86. Research and Development Division, AEC, ORO

87-88. Babcock and Wilcox Co., Nuclear Division, Lynchburg, Va. (1 copy each to G. C. Robinson and and A. H. Lazar)

89. Ebasco Co., New York (R. H. Jordan)

90-93. Phillips Petroleum Co. (1 copy each to L. J. Weber, Warren Francis, V. A. Wolker, and D. R. deBoisblanc)

94. AEC, Idaho Office (Don Williams)

95. AEC, Washington (E. E. Sinclair)

96. AEC, ORO (H. W. Behrman)

97-684. Given distribution as shown in TID-4500 (26th ed.) under Chemistry category (75 copies - OTS) 